\title{
Newly identified Carboniferous units (the Pointe Sawyer and Chemin-des-Pêcheurs formations) in the Gaspé Peninsula, Quebec; implications regarding the evolution of the northwestern sector of the Maritimes Basin
}

\author{
Pierre Jutras, Gilbert Prichonnet, and John Utting
}

\begin{abstract}
The Upper Member of the Cannes-de-Roches Formation was recently recognized overlying the Bonaventure Formation in the New Carlisle area, over $100 \mathrm{~km}$ southwest of the previously documented exposures of this unit. Moreover, remnants of the La Coulée Formation, which are unconformably overlain by the Bonaventure Formation, have also been recognized underlying, with a similar type of contact, the Lower Member of the Cannes-de-Roches Formation. From this and from facies similarities, the Lower and Middle members of the Cannes-de-Roches Formation are now considered to be equivalent to the Bonaventure Formation. It is proposed to abandon these two member designations and to only keep the Bonaventure Formation. The remaining Upper Member of the Cannes-de-Roches Formation is renamed the Pointe Sawyer Formation. A late Viséan to early Namurian age is attributed to this grey clastic formation from spore analysis. Dark reddish-brown sandstone conformably overlie the Pointe Sawyer Formation in the Mal Bay area. They correspond to the beginning of sedimentation from more distant sources within the regional Carboniferous stratigraphic succession, which was until then characterized by sedimentation from proximal sources. This previously unidentified unit is here referred to as the Chemin-des-Pêcheurs Formation.
\end{abstract}

\begin{abstract}
Résumé : Le Membre Supérieur de la Formation de Cannes-de-Roches a récemment été identifié recouvrant la Formation de Bonaventure dans la région de New Carlisle, plus de $100 \mathrm{~km}$ au sud-ouest des affleurements qui furent antérieurement documentés pour cette unité. De plus, la couverture résiduelle discontinue de la Formation de La Coulée, recouverte en discordance par la Formation de Bonaventure, a aussi été identifiée sous le Membre Inférieur de la Formation de Cannes-de-Roches, montrant avec celui-ci le même type de contact. L'ensemble de ces faits mis de pair avec la similitude des faciès font que les membres Inférieur et Moyen de la Formation de Cannes-de-Roches sont maintenant considérés comme les équivalents de la Formation de Bonaventure. Il est proposé d'abandonner ces deux membres et de ne conserver que la Formation de Bonaventure. Le Membre Supérieur restant est renommé Formation de Pointe Sawyer. Un âge Viséen tardif à Namurien précoce est attribué à cette formation clastique grise de par l'analyse de spores. Des grès bruns rougeâtres foncés recouvrent de façon concordante la Formation de Pointe Sawyer dans la région de La Malbaie. Ils correspondent au début d'une sédimentation provenant de sources plus distales à l'intérieur de la succession stratigraphique carbonifère régionale, laquelle était jusqu'alors caractérisée par une sédimentation provenant de sources proximales. Cette unité stratigraphique est nouvellement identifiée et est ici définie en tant que Formation du Chemin-des-Pêcheurs.
\end{abstract}

\section{Introduction}

The Carboniferous stratigraphy in the northwesternmost sector of the upper Paleozoic Maritimes Basin (southeastern Canada), in the area of the Gaspé Peninsula, was included

Received September 27, 1999. Accepted July 7, 2000.

Published on the NRC Research Press Web site on

November 29, 2000.

Paper handled by Associate Editor M. Coniglio.

P. Jutras ${ }^{1}$ and G. Prichonnet. GEOTERAP, Département des Sciences de la Terre, Université du Québec à Montréal, C.P. 8888, Succ. Centre-Ville, Montréal, QC H3C 3P8, Canada.

J. Utting. Geological Survey of Canada (Calgary), 3303-33rd St. NW, Calgary, AB T2L 2A7, Canada.

${ }^{1}$ Corresponding author (e-mail: d322144@er.uqam.ca) within the Bonaventure Formation by Logan (1846). It was later subdivided into the Cannes-de-Roches and Bonaventure formations (Figs. 1, 2) by Alcock (1935), who also excluded the red clastic sedimentary rocks of the Malbaie Formation (Devonian) from the Bonaventure Formation.

Alcock (1935) subdivided the Cannes-de-Roches Formation into three members: a Lower Member dominated by red conglomeratic breccia, a Middle Member mainly composed of red mudstone, and an Upper Member mainly composed of grey sandstone and conglomerate with carbonized plant remains (see also Rust 1981). The more extensive Bonaventure Formation is mainly composed of red conglomercjesate, sandstone, and mudstone. Paleosol overprints are common in both formations.

Of all these units, only the Upper Member of the Cannesde-Roches Formation has yielded spores for dating, although no details concerning the composition of the assemblages 
Fig. 1. Late Paleozoic stratigraphic record in the Maritimes and in the Gaspé Peninsula. Time scale after Harland et al. (1990). Crosshatching represent hiatuses; wavy lines represent deformation events.

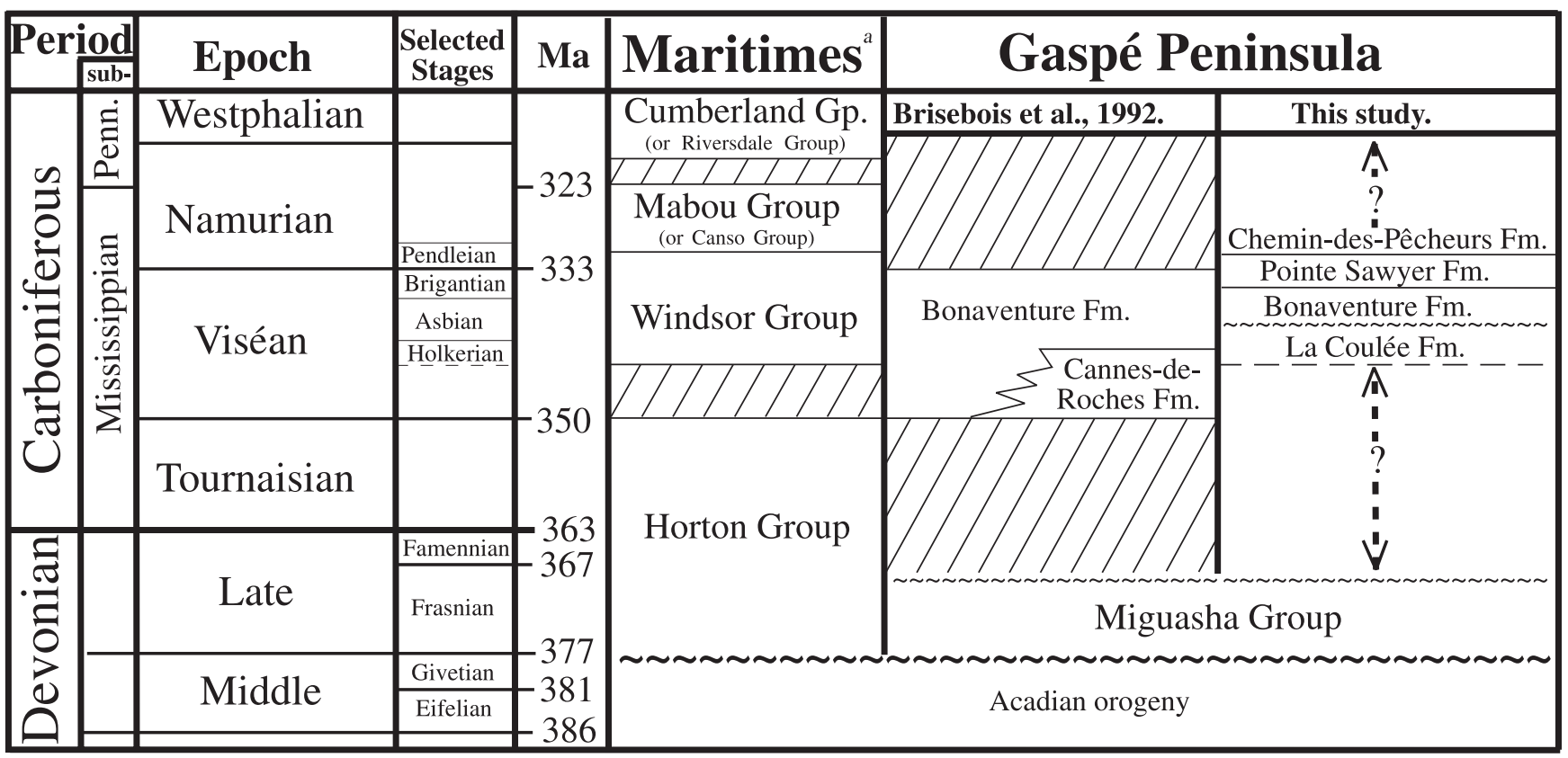

a Modified from Bell (1944), Mamet (1970), Howie and Barss (1975), Utting (1987), Utting et al. (1989b), and Ryan et al. (1991).

Fig. 2. Location of the study area. Rectangular blocks $3 \mathrm{~A}$ and $3 \mathrm{~B}$ indicate the two specific study areas mapped on Fig. 3. Also shown are the nine localities (1-9) where thick groundwater calcretes, remnants of the La Coulée Formation, have been identified underneath the Cannes-de-Roches and Bonaventure formations. The geology is from Brisebois et al. (1992). The inset is modified from Gibling et al. (1992), with dark and pale shadings representing, respectively, the inland and offshore rocks of the Maritimes Basin.

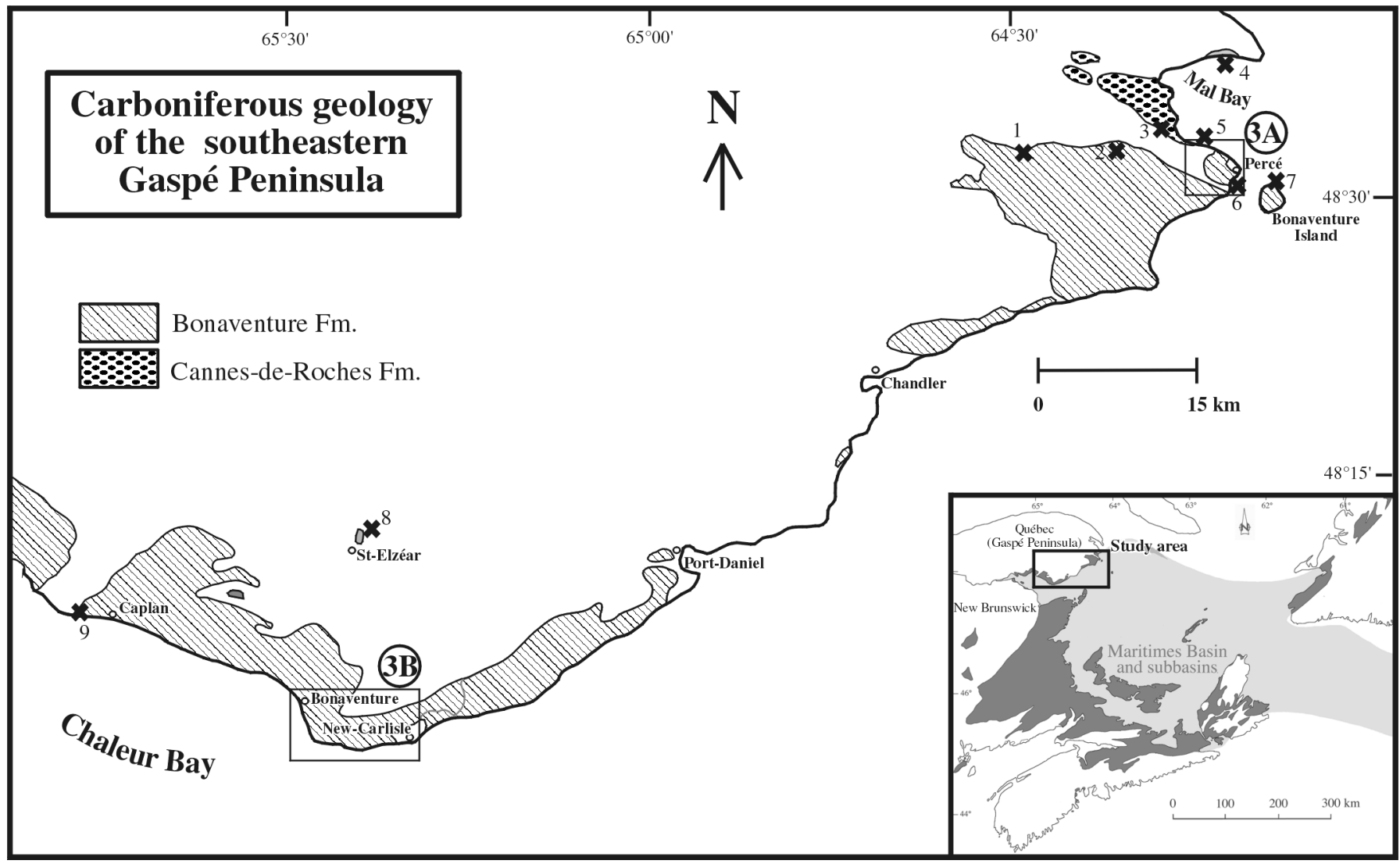


Fig. 3. The two specific study areas (A, B) showing the location of the three composite columns on Fig. 4. (A) Geology of the Percé area, modified from Kirkwood (1989), with the location of columns 4A (Cannes-de-Roches Cove sequence) and 4B (Percé-Beach Mont Sainte-Anne sequence). C.-d.-R., Cannes-de-Roches. (B) Geology of the New Carlisle area, modified from Brisebois et al. (1992), with the location of column 4C (New-Carlisle sequence).

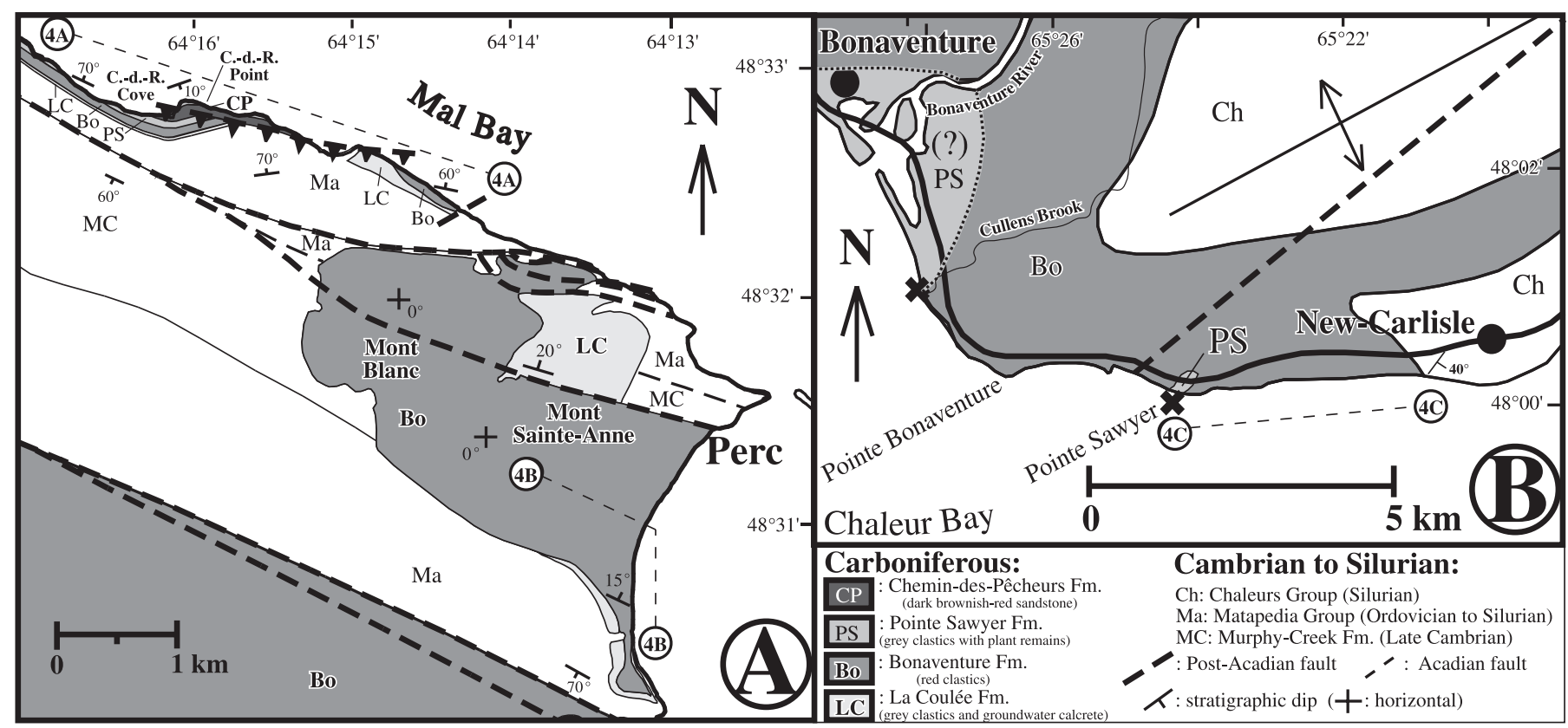

have been previously published. Hacquebard (1972) and Barss in Hacquebard (1972) suggested an early Namurian age (c/b zone) for the spores, whereas Barss (personal communication in Rust 1981) proposed a Viséan age. The entire succession is interpreted as the product of fault-related continental sedimentation (Rust et al. 1989).

The stratigraphic relationship between the two formations has never been clear. Since Alcock (1935), the hypothesis that they are penecontemporaneous, but deposited in two distinct Carboniferous basins separated by a thin ridge of pre-Acadian rocks, has prevailed. Kirkwood (1989) mentioned an interdigitation between the Bonaventure and Cannes-de-Roches formations in the Percé area and considered the Cannes-de-Roches as contemporaneous with the basal beds of the Bonaventure Formation. This idea was subsequently adopted by Brisebois et al. (1992) (Fig. 1).

van de Poll (1995) considered the Bonaventure Formation as a Windsor-Canso (Windsor-Mabou, sensu Ryan et al. 1991) equivalent, and the Cannes-de-Roches as a CansoRiversdale (Mabou-Cumberland, sensu Ryan et al. 1991) equivalent. The correlations of van de Poll (1995), thus, place the Cannes-de-Roches Formation higher in the stratigraphy than the Bonaventure Formation, which contradicts Kirkwood (1989) and Brisebois et al. (1992).

A third Carboniferous unit, the La Coulée Formation, has been recently identified in the Gaspé Peninsula (Jutras et al. 1999). The erosional remnants of this formation are unconformably overlain by the Bonaventure Formation at different localities in the southern Gaspé Peninsula (Fig. 2).

New field data collected during a review of the Carboniferous series in the Gaspé Peninsula have cast doubt regarding the current interpretation of the stratigraphic record. A thick, discontinuous groundwater calcrete, typical of the erosional remnants of the La Coulée Formation, is not only found underneath the Bonaventure Formation but has also been identified below the lithologically similar Cannes-deRoches Formation at various localities (Fig. 2). Moreover, a plant bearing facies identical to that of the Cannes-deRoches Upper Member has been identified overlying the Bonaventure Formation in two outcrops along the coast between the towns of New Carlisle and Bonaventure.

These new data have demonstrated the need to reevaluate the stratigraphic relationship between the Cannes-de-Roches and Bonaventure formations. The two formations are examined in this paper using facies analysis from outcrops and thin sections, stratigraphic correlation, paleocurrent measurements, calcimetry, X-ray diffraction, and palynology. Full description is provided for three composite sections from two specific study areas (Figs. 3, 4). A new stratigraphic framework and more detailed paleoenvironmental reconstructions are proposed. Also, an attempt is made to correlate the northern Chaleur Bay units with those of the rest of the Maritimes Basin.

\section{Sedimentary facies description}

The Cannes-de-Roches Cove sequence (Figs. 3A, 4A)

This section is located on the south shore of Mal Bay. The direct contact between this subvertically tilted post-Acadian sequence and its basement is obscured by brittle sliding of the basal Carboniferous strata on the underlying basement rocks, which probably occurred during the deformation episode that led to nearly vertical tilting of the strata. A massive calcrete up to $12 \mathrm{~m}$ thick overlies the Ordovician to Silurian limestone basement of the Matapedia Group (Fig. 2, locality 5). Rust (1976) identified a thinner section of this basal calcrete near Belle-Anse, on the north shore of Mal Bay (Fig. 2, locality 4), but the thick south shore outcrops, which 
Fig. 4. Post-Acadian stratigraphy of the southeastern Gaspé Peninsula. (A) Composite column of the Cannes-de-Roches Cove sequence. (B) Composite column of the Percé-Beach - Mont Sainte-Anne sequence. (C) Composite column of the New-Carlisle sequence.

Table 1. Mineralogical composition of various units in the Carboniferous series of the Gaspé Peninsula from calcimetry (*) and X-ray diffraction.

\begin{tabular}{|c|c|c|c|c|c|c|c|c|}
\hline Sample & Unit & $\begin{array}{l}\text { Calcite } \\
(\%)\end{array}$ & $\begin{array}{l}\text { Quartz } \\
(\%)\end{array}$ & $\begin{array}{l}\text { K-feldspar } \\
(\%)\end{array}$ & $\begin{array}{l}\text { Plagioclase } \\
(\%)\end{array}$ & $\begin{array}{l}\text { Muscovite } \\
(\%)\end{array}$ & $\begin{array}{l}\text { Chlorite } \\
(\%)\end{array}$ & $\begin{array}{l}\text { Hematite } \\
(\%)\end{array}$ \\
\hline 1 & Cal-LC & 84.83 & 13.34 & 1.83 & $\mathrm{x}$ & $\mathrm{x}$ & $\mathrm{x}$ & $\mathrm{x}$ \\
\hline 2 & Cal-LC & 89.17 & 8.81 & 0.96 & $\mathrm{x}$ & $\mathrm{x}$ & $\mathrm{x}$ & $\mathrm{x}$ \\
\hline $3 *$ & Cal-LC & 90.91 & & & & & & \\
\hline 4 & Cal-Bon & 95.47 & 3.46 & $\mathrm{x}$ & 0.19 & $\mathrm{x}$ & $\mathrm{x}$ & 0.19 \\
\hline 5 & Cal-Bon & 98.12 & 0.16 & $\mathrm{x}$ & $\mathrm{x}$ & 0.29 & 1.42 & $\mathrm{x}$ \\
\hline $6^{*}$ & Cal-Bon & 97.85 & & & & & & \\
\hline $7 *$ & Cal-Bon & 91.51 & & & & & & \\
\hline $8 *$ & Cal-Bon & 88.7 & & & & & & \\
\hline 9 & Cal-CdR & 81.01 & 13.92 & 0.54 & 0.31 & 0.65 & 0.58 & 0.19 \\
\hline $10 *$ & Cal-CdR & 95.45 & & & & & & \\
\hline $11^{*}$ & Gss-LC & 87.04 & & & & & & \\
\hline $12 *$ & Gss-LC & 79.0 & & & & & & \\
\hline 13 & Rss-Bon & 86.74 & 5.3 & 4.08 & 0.06 & 0.33 & 0.37 & 0.06 \\
\hline 14 & Rrss-Bon & 11.6 & 77.71 & 1.67 & $\mathrm{x}$ & 0.35 & $\mathrm{x}$ & 0.27 \\
\hline $15^{*}$ & Rss-Bon & 36.8 & & & & & & \\
\hline $16^{*}$ & Rss-Bon & 39.4 & & & & & & \\
\hline $17 *$ & Rss-Bon & 28.4 & & & & & & \\
\hline $18^{*}$ & Rss-Bon & 14.95 & & & & & & \\
\hline 19 & Rss-CdR & 34.49 & 59.18 & 4.78 & $\mathrm{x}$ & 0.56 & 0.44 & 0.12 \\
\hline $20 *$ & Rss-CdR & 14.25 & & & & & & \\
\hline 21 & Gss-PS & 38.4 & 54.71 & 0.46 & 1.15 & 1.15 & 2.99 & $\mathrm{x}$ \\
\hline 22 & Gss-CdR & 27.11 & 71.2 & $\mathrm{x}$ & $\mathrm{x}$ & 0.12 & 0.98 & 0.46 \\
\hline $23^{*}$ & Gss-CdR & 15.76 & & & & & & \\
\hline $24 *$ & Gss-CdR & 16.09 & & & & & & \\
\hline 25 & CP-trans & 20.56 & 76.83 & $\mathrm{x}$ & $\mathrm{x}$ & $\mathrm{x}$ & 2.0 & 0.21 \\
\hline $26^{*}$ & CP-trans & 9.11 & & & & & & \\
\hline $27 *$ & CP-trans & 6.79 & & & & & & \\
\hline 28 & $\mathrm{CP}$ & $\mathrm{x}$ & 97.6 & 0.07 & 0.12 & 0.16 & 1.58 & 0.23 \\
\hline $29^{*}$ & $\mathrm{CP}$ & 0.2 & & & & & & \\
\hline $30 *$ & $\mathrm{CP}$ & 0.2 & & & & & & \\
\hline
\end{tabular}

Note: Cal-LC, thick basal calcrete in the grey clastics of the La Coulée Formation; Cal-Bon, thick calcrete underneath the Bonaventure Formation; Cal-CdR, thick calcrete underneath the Cannes-de-Roches Formation; Gss-LC, grey sandstone amid the conglomeratic facies of the La Coulée Formation; Rss-Bon, red sandstone of the Bonaventure Formation; Rss-CdR, red sandstone of the Cannes-de-Roches Formation; Gss-PS, grey sandstone with plant remains from Pointe Sawyer Formation; Gss-CdR, grey sandstone with plant remains from the Upper Member of the Cannes-de-Roches Formation; CP-trans, transitional facies from the grey clastics with plant remains to the dark reddish-brown sandstone (pinkish-grey, cross-bedded sandstone) in the Cannes-de-Roches Cove; CP, dark reddish-brown sandstone from the Cannes-de-Roches Cove.

are relatively inaccessible, have not previously been reported.

As shown in Table 1 (samples 9 and 10) and Fig. 5A, the calcrete matrix is composed of over $80 \%$ calcite. It is also rich in silica. Scarce floating clasts are disseminated throughout the calcrete and become progressively more rounded and abundant going up the section. Limestone and volcanic clasts are most abundant and are often silicified.

Red clastic sedimentary rocks overlie the calcrete with a sharp contact (Fig. 6). The lower 15-20 m are conglomeratic breccia, with clasts mainly composed of siliceous limestone from local sources. The beds bearing more rounded clasts include abundant quartz pebbles and occasional red jasper. Large subangular red jasper clasts have also been found in coarse breccia. These coarse redbeds correspond to what has been referred to as the Lower Member of the Cannes-deRoches Formation (Alcock 1935). They are followed by the 30-35 m thick Middle Member, composed of gradually fining-upward alternations of coarse-grained and fine-grained redbeds with abundant nodular paleosol overprints and green mineralization haloes (Fig. 7). Similar haloes are also found in the Bonaventure Formation at various localities along the Chaleur Bay shore cliffs, notably at Caplan (Fig. 2). Calcrete hardpans in mudstone are found within the topmost metres of the Middle Member.

The clastic redbeds are overlain by $\sim 20 \mathrm{~m}$ of grey clastic sedimentary rocks with carbonized plant remains (Fig. 8), which were assigned to the Upper Member of the Cannes- 


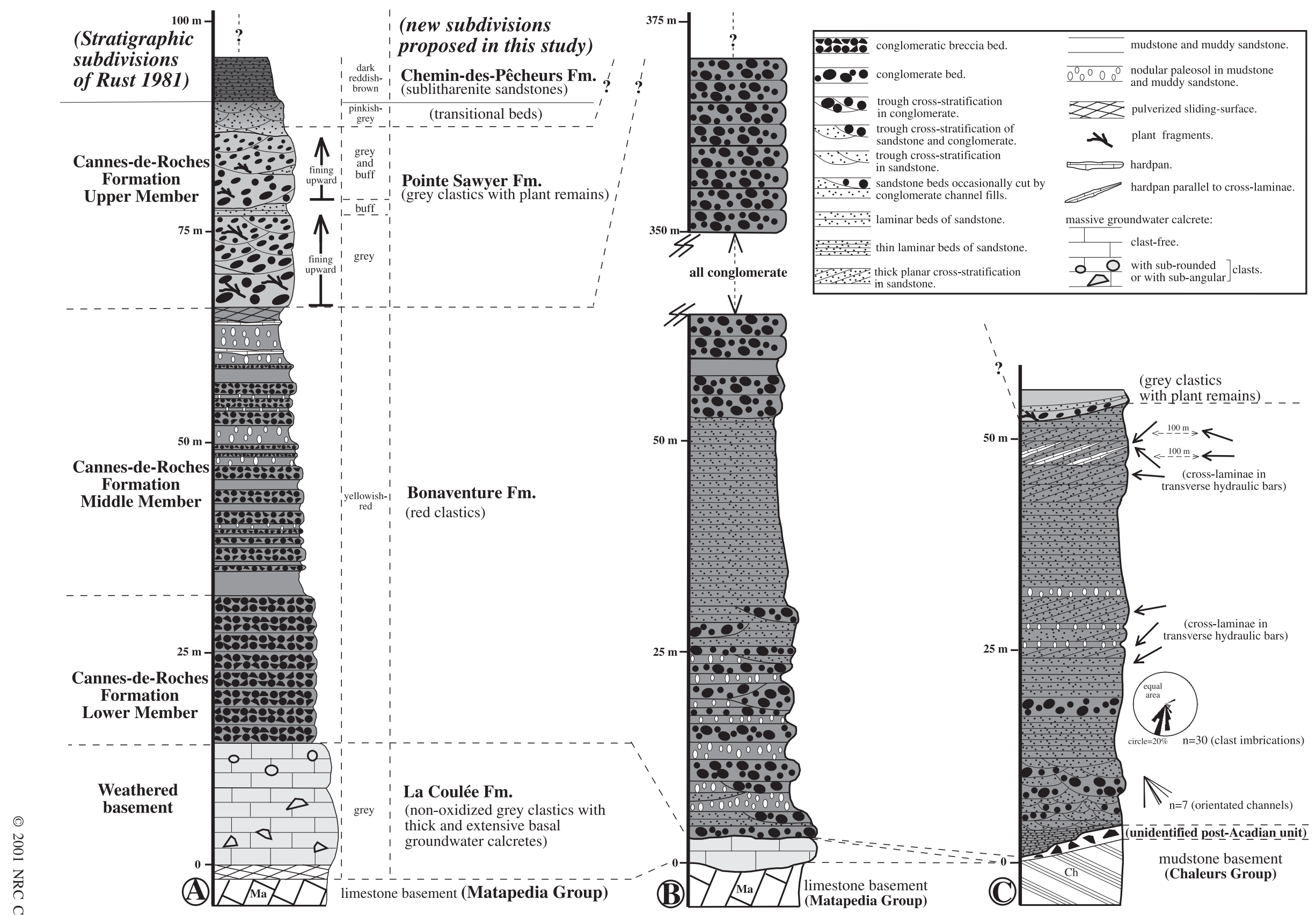


Fig. 5. Average calcite content in the Carboniferous series of the southern Gaspé Peninsula according to numbers from Table 1. (A) Mal Bay exposures (Cannes-de-Roches Formation). (B) Chaleur Bay exposures. (C) cumulative average for each general facies.
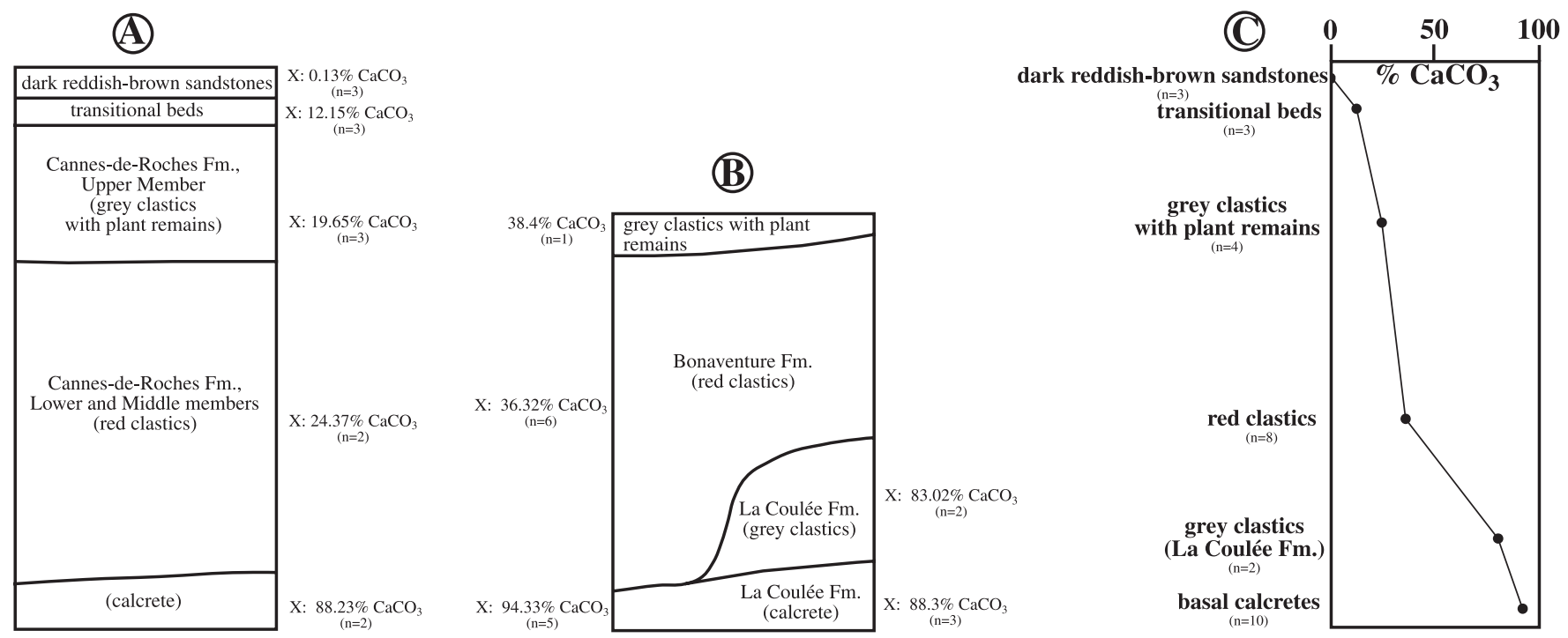

Fig. 6. Contact between the basal groundwater calcrete and the overlying red clastics of the formerly called Lower Member of the Cannes-de-Roches Formation.

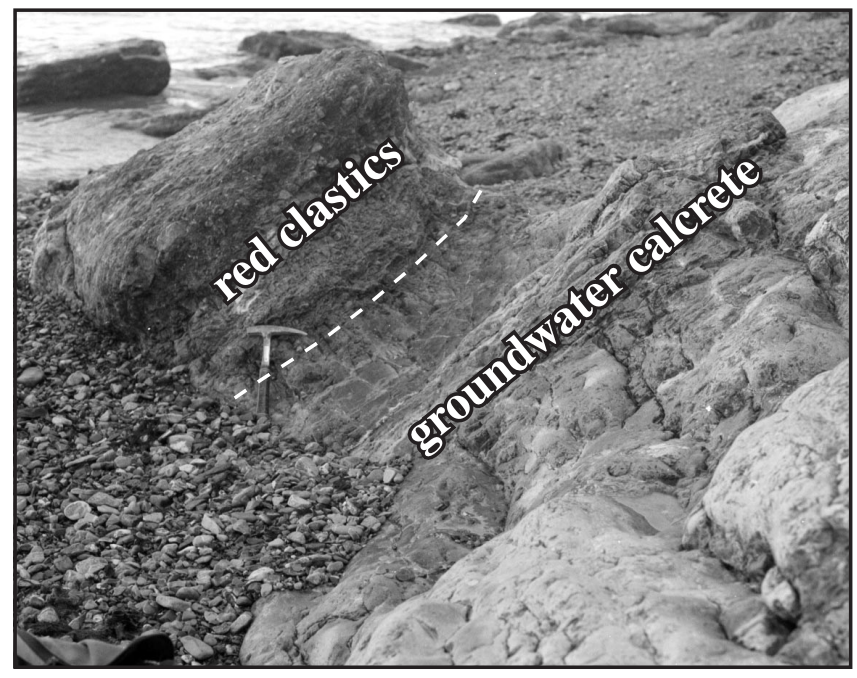

de-Roches Formation by Alcock (1935). The difference in competence between the first grey beds and the underlying redbeds has brought the former to slide on the latter during posterior gravity-induced collapsing within the subvertical sections of the Cannes-de-Roches Cove, a coastal erosion process that is still currently active. The uppermost mudstone beds are crumbled, which greatly limits interpretation of their contact with the overlying grey clastic sedimentary rocks.

Such brittle sliding of large slabs, which can be more than $100 \mathrm{~m}$ wide, has extensively affected the subvertical sections at Cannes-de-Roches Cove. As these slabs are lying flat on each other, they can easily be confused for continuous strata and attempts to trace back the stratigraphy have to be made with caution, otherwise erroneous thicknesses may be obtained. For example, Rust (1981) recorded an inflated thick-
Fig. 7. Alternations of (a) fine red conglomeratic breccia and (b) sandy mudstone beds with pedogenic features in the formerly called Middle Member of the Cannes-de-Roches Formation.

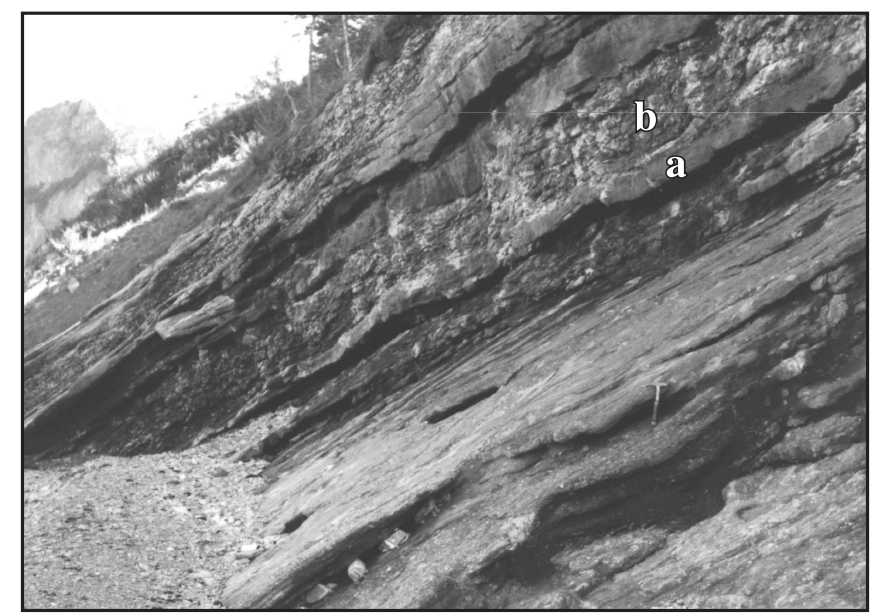

ness of almost $40 \mathrm{~m}$ for the Upper Member of the Cannesde-Roches Formation, whereas we obtained a thickness of only $20 \mathrm{~m}$ for the same strata.

Braided conglomerate channel fills are dominant in the Upper Member. In 1997, a 1-2 m layer of buff sandstone separating two fining-upward conglomeratic units could be observed in a $20 \mathrm{~m}$ thick outcrop. Unfortunately, since then, the upper conglomeratic unit has collapsed into the sea, along with the underlying buff sandstone, and no continuous section of the Upper Member remains, although slabs of both fining-upward units can still be observed in their entire thickness.

Clast composition in the Upper Member is slightly more polygenetic than in the underlying redbeds, but locally derived limestone clasts are still largely dominant in the conglomerates as are limestone grains in the lithic graywackes (sensu Pettijohn 1975), which are the dominant type of sand- 
Fig. 8. Carbonized piece of wood (between the dot lines) at the contact between the grey clastics of the Cannes-de-Roches Cove (formerly called the Upper Member of the Cannes-de-Roches Formation) and the overlying pinkish-grey transitional beds.

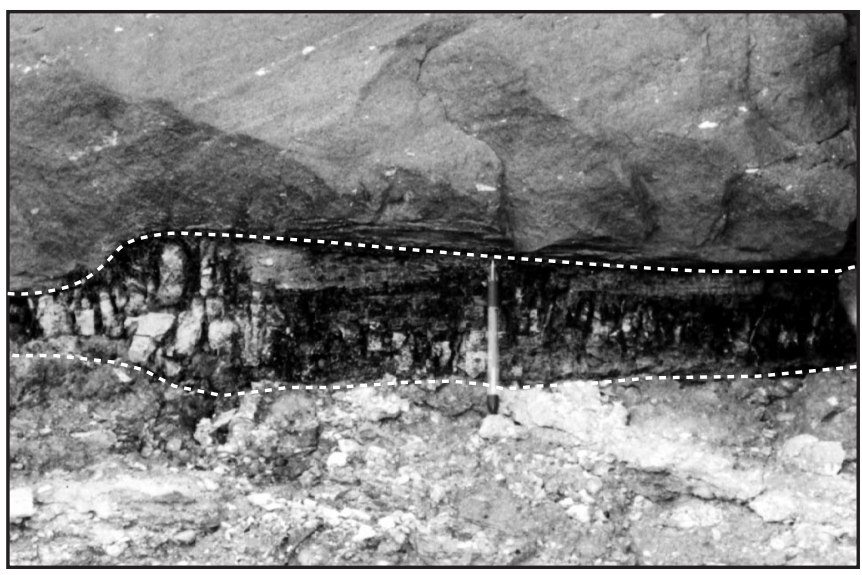

stone in both units and which can be regarded as the continental equivalents of packstones (sensu Dunham 1962). This suggests that the source was very local, even for the sandstones. The unabraded and unsorted nature of the coaly fragments also suggest relatively short transportation by water prior to deposition.

The grey clastic sedimentary rocks with plant remains of the Upper Member pass upward into 4-5 m of pinkish-grey cross-bedded sandstone, which gradually becomes dark reddish-brown along with a progressively reduced content in calcite and plant remains (Fig. 5 and samples 25, 26, 27 in Table 1). Several large pieces of carbonized wood can be observed parallel to bedding between the grey clastic sedimentary rocks and the pinkish-grey beds (Fig. 8).

The remaining 5-6 $\mathrm{m}$ of the sequence are dark reddishbrown laminated sandstone (Fig. 9) with no more than $0.2 \%$ calcite and $97.6 \%$ quartz (Table 1, samples 28-30). There is $15-25 \%$ porosity in this poorly cemented sandstone, which was partly caused by recent subsoil weathering and which may lead to an underestimation of the original calcite content. However, based on the observation of small nonporous areas on thin sections, the matrix and cement that have been removed by weathering were apparently clay-rich and nearly calcite-free. Although some clasts may also have been removed, it is inferred that limestone grains were absent prior to weathering, because they were already absent from the well-preserved rocks of the underlying pinkish-grey transitional beds.

Although X-ray diffraction indicates $97.6 \%$ quartz, these sandstones include 10-15\% lithic fragments, many of which are strongly silicified. The sandstones are, therefore, still relatively immature and classify as sublitharenite (Pettijohn 1975). The original thickness of this previously unidentified dark reddish-brown sandstone unit is unknown and only $10 \mathrm{~m}$, including the transitional pinkish-grey beds, have been recognized.

\section{The Percé-Beach - Mont Sainte-Anne sequence (Figs. 3A, 4B)}

The basement, consisting of limestone of the Matapedia Group, is separated from the clastic redbeds of the
Fig. 9. Laminar beds of the dark reddish-brown sandstone at the Cannes-de-Roches Point.

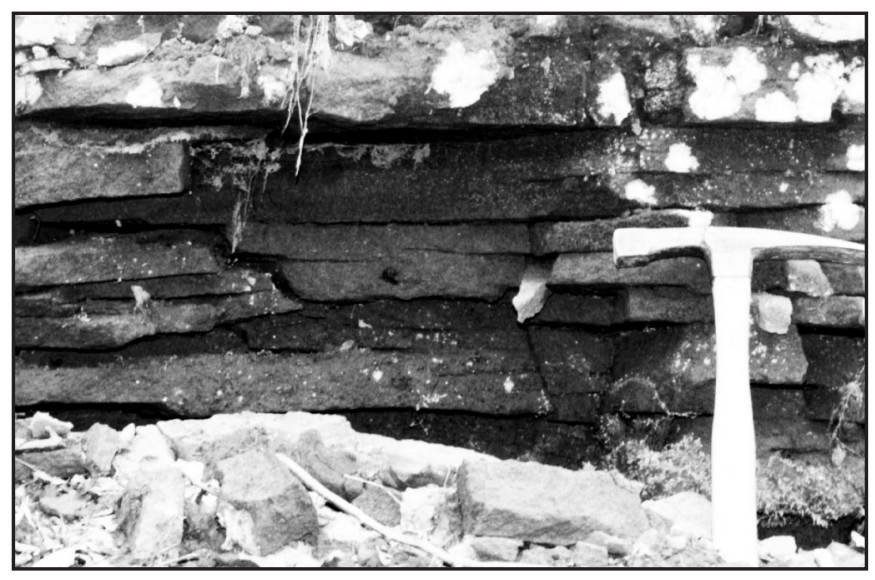

Bonaventure Formation by a 4-5 m-thick groundwater calcrete that has been interpreted as an erosional remnant of the La Coulée Formation by Jutras et al. (1999). The contact between the basement and the calcrete is clear but not sharp, the topmost metre of the basement being affected by calcretization.

The contact with the overlying red clastic sedimentary rocks is sharper. Red conglomerate and muddy, nodular paleosols, with a very high lateral variability, occupy most of the lowest $25 \mathrm{~m}$. They are followed by $\sim 25 \mathrm{~m}$ of laminated sandstone with thin interbeds of mudstone. The remaining $300 \mathrm{~m}$ of the sequence, which forms the Mont Sainte-Anne outlier, is composed of massive conglomeratic beds, several metres thick.

Clast composition in the conglomerate includes $65-80 \%$ limestone, 5-15\% clastic rocks, 10-20\% quartz pebbles, and disseminated red jasper (according to three petrographic counts; $N=112$ ). The conglomerate lack internal structures such as clearly defined clast imbrication and intrabed stratification. As there is no overlying formation, total thickness of the Bonaventure Formation in the Percé area is unknown.

\section{The New-Carlisle sequence (Figs. 3B, 4C)}

The mudstone basement on the west side of New Carlisle belongs to the Late Silurian Indian Point Formation of the Chaleurs Group (Bourque and Lachambre 1980). A 2 m erosional remnant of an unidentified clastic formation (research in progress) separates the pre-Acadian basement from the red clastic sedimentary rocks of the Bonaventure Formation. There is no remnant of the La Coulée Formation calcrete underlying the Bonaventure Formation in this area, but a $3 \mathrm{~m}$ thick calcrete underlies that formation at Caplan (Fig. 2, locality 9), $36 \mathrm{~km}$ to the west-northwest, and a $12 \mathrm{~m}$ calcrete underlies that formation at Saint-Elzéar (Fig. 2, locality 8), $22 \mathrm{~km}$ to the north-northwest (Jutras et al. 1999).

Planar beds of sandstone occupy the first few metres of the sequence, passing into $\sim 7 \mathrm{~m}$ of trough cross-stratified sandstone and conglomerate. Locally derived volcanic and sedimentary rocks of the Chaleurs Group (Silurian) and of the unidentified basal post-Acadian clastic unit form the bulk of the clasts in the conglomerate. Quartz pebbles form $\sim 15 \%$ of the $1-5 \mathrm{~cm}$ clast fraction $(n=30)$ and disseminated red jasper clasts are common. The overlying $15 \mathrm{~m}$ are mo- 
Fig. 10. Thick and laterally persistent planar cross-strata in the Bonaventure Formation near Pointe Sawyer.

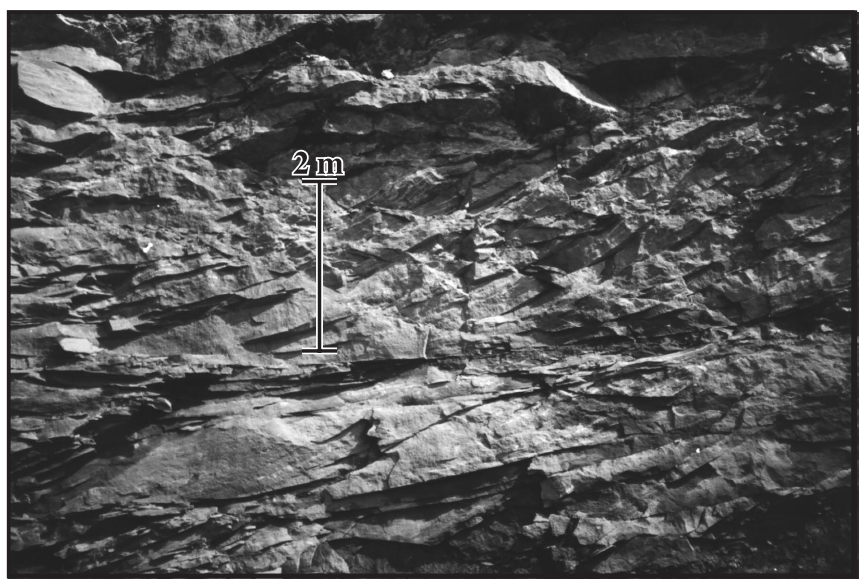

notonous planar beds of sandstone, locally incised by a large $\sim 3 \mathrm{~m}$ thick conglomerate bed.

Close to the $25 \mathrm{~m}$ level, a series of large and laterally persistent planar cross-sets, up to $3 \mathrm{~m}$ thick, appear and remain abundant throughout the upper half of the Bonaventure Formation in this area (Fig. 10). The first occurrences are intercalated with nodular, muddy paleosols. They are followed by $\sim 9 \mathrm{~m}$ of thickly bedded sandstone and a second series of thick planar cross-sets. In one of these beds, several 10$15 \mathrm{~cm}$ thick hardpans, composed of up to $100 \%$ calcite, have formed parallel to the cross-sets and oblique to the general bedding (Fig. 11).

A channel fill of grey clastic sedimentary rocks with plant remains, identical to the Upper Member of the Cannes-deRoches Formation, but over $100 \mathrm{~km}$ southwest of Cannesde-Roches Cove, cuts through the uppermost laminar sandstones of the Bonaventure Formation at Pointe Sawyer (Figs. 12A, 12B). A lag of coarse Bonaventure Formation clasts occupies the bottom of the channel (Fig. 12C). This is followed by $\sim 1 \mathrm{~m}$ of grey conglomerate and sandstone showing numerous vertical changes in the granulometry, which indicate flow intensity variations and which are typical of fluvial environments. The upper $3 \mathrm{~m}$ are grey mudstone intercalated with thin beds of grey sandstone. The contact between the red clastic sedimentary rocks of the Bonaventure Formation and the first metre of overlying grey clastic sedimentary rocks has also been observed at one more site, at the mouth of Cullens Brook, $4 \mathrm{~km}$ to the west (Fig. 3B). This outcrop can only be observed at low tide.

Numerous large boulders up to several metres in maximum diameter of the grey clastic facies with plant remains have been washed out of till material by coastal erosion and are abundant on the beach between the two sites, especially near the Cullens Brook outcrop. From the size of these blocks, it can be concluded that more extensive remnants of the same facies likely exist in the gentle synclinal structure where the Bonaventure River delta is located to the north, upstream from the general glacial flow established by Veillette and Cloutier (1993). This depression, however, is occupied by thick Quaternary material and recent alluvium. Mapping of the grey clastic sedimentary rocks with plant remains in the Bonaventure River delta (PS, Pointe Sawyer in
Fig. 11. Calcrete hardpan parallel to cross-laminae in a thick tabular cross-bedded unit.

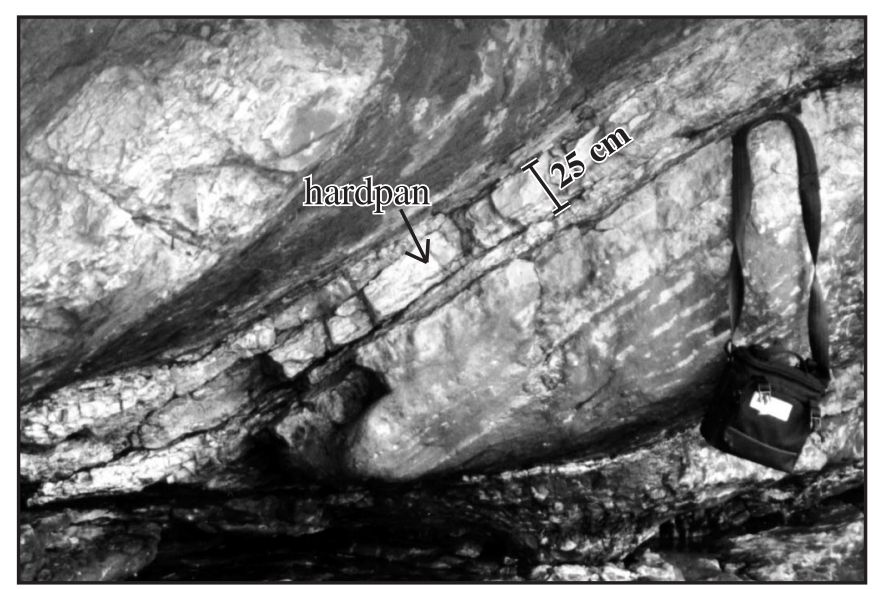

Fig. 3B) is, therefore, a cartographic extrapolation from only one bedrock exposure at the periphery of this well-buried area.

\section{Palynostratigraphy}

Seven mudstone samples were collected for palynological analysis from the Pointe Sawyer locality and eight from the Cannes-de-Roches Cove locality; all but one sample from each contained well-preserved palynomorphs (Fig. 13). The assemblages are similar (Appendix 1), and in terms of the zonal scheme proposed by Utting (1987), the presence of Schopfipollenites acadiensis, Knoxisporites triradiatus, Rugospora corporata var. verrucosa indicates an age no older than the Schopfipollenites acadiensis - Knoxisporites triradiatus (AT) Zone. However, in some samples, rare specimens of Ibrahimispores magnificus indicate a correlation with the younger Grandispora spinosa - Ibrahimispores magnificus (SM) Zone, although other taxa diagnostic of that zone, such as Grandispora spinosa, Raistrickia nigra, Schulzospora bilunata, and Tricidarisporites arcuatus, were not seen.

Based partly on comparison with the spore zones of western Europe (e.g., Clayton et al. 1977), the SM Zone was assigned a Brigantian (late Viséan) age by Utting (1987). However, even in western Europe the Viséan-Namurian boundary is difficult to place from palynological criteria, and thus here, where only limited data are available, a Brigantian to Pendleian (early Namurian) age range is suggested. In terms of lithostratigraphic units of Nova Scotia, this places the intervals studied at the Windsor-Mabou (Canso) boundary (Fig. 1), a conclusion similar to that reached by earlier workers (Hacquebard 1972 and Barss, in Hacquebard 1972).

The good spore preservation suggests a neutral environment at the sediment water interface that was neither oxic nor anoxic. One specimen of a spinose acritarch (Veryhachium sp.) was found in sample C-412602. If in situ, this would suggest a marine environment of deposition, but it is more probably reworked from older rocks. The colour of the spores is orange to dark reddish-yellow, indicating a Thermal Alteration Index of TAI 2 (Utting et al. 1989a), which is within the "oil window." 
Fig. 12. Grey clastics with plant remains (PS) at Pointe Sawyer. (A) Channellized contact with the underlying Bonaventure Formation (Bo). (B) Carbonized piece of wood. (C) Lag of Bonaventure Formation material at the bottom of the channel fill.

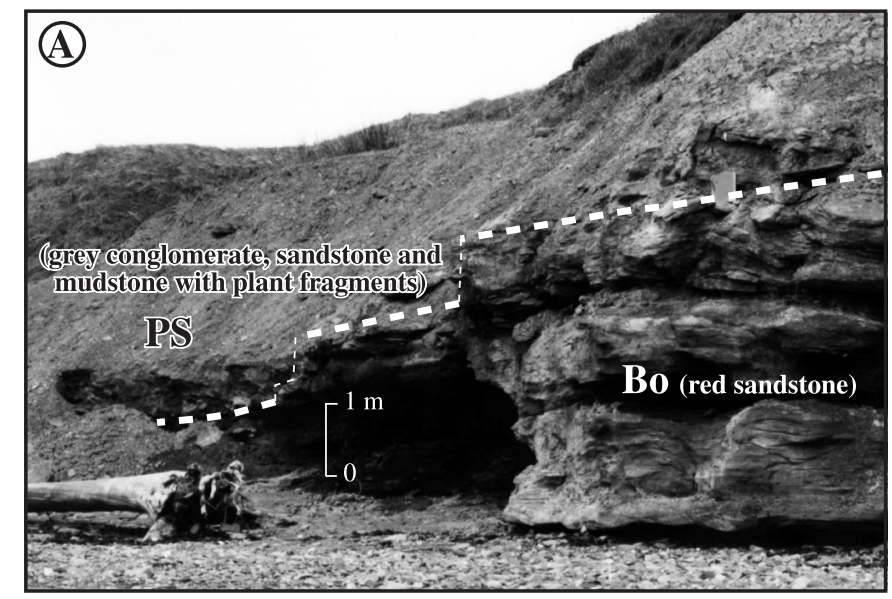

\section{Paleocurrent data in the Bonaventure Formation}

Numerous paleocurrent measurements were taken in the Bonaventure Formation from 5-15 cm wide and 10-15 cm thick grooves at the base of breccia beds in the Percé area and from orientated $0.5-10 \mathrm{~m}$ wide conglomeratic channels in braided systems at various localities (Fig. 14). Only the most reliable features, where paleocurrent directions could not be mistaken, were taken into account. According to these measurements, the paleoflow direction is steadily to the south between Chandler and Percé, in the east part of the basin, and to the southeast between Chandler and Caplan.

Other measurements were taken from the laminae of thick (1-3 m) and laterally persistent tabular cross-bedded units, such as the ones shown on Fig. 10. (1) The lateral persistence of these beds, over hundreds of metres, (2) the vertical succession of several sets in some cases, and (3) the lack of trend reversals imply that they were probably not deposited by lateral accretion on longitudinal bars, but were rather deposited by avalanche on prograding transverse hydraulic bars. The laminae, therefore, most likely dip in the currentflow direction. In the three areas in which such structures were identified, paleocurrent measurements suggest a drainage to the west or the southwest.

The exact stratigraphic level in which measurements were taken could not always be determined due to insufficient exposure. The change in paleocurrent orientation with time can best be observed within the continuous New-Carlisle sequence (Fig. 4C). There, current directions change from a southeast orientation, in the coarse deposits of the lower half, to a northwest-to-southwest orientation, in the finer deposits of the upper half. Reliable paleocurrent measurements could not be made in the Bonaventure Formation facies of the two other sequences (Fig. 4A, 4B).

\section{Paleoenvironmental interpretations and stratigraphic subdivisions}

\section{The La Coulée Formation (calcretized clastics)}

Rust (1982) considered that the calcrete separating the Cannes-de-Roches Formation from the Malbaie Formation

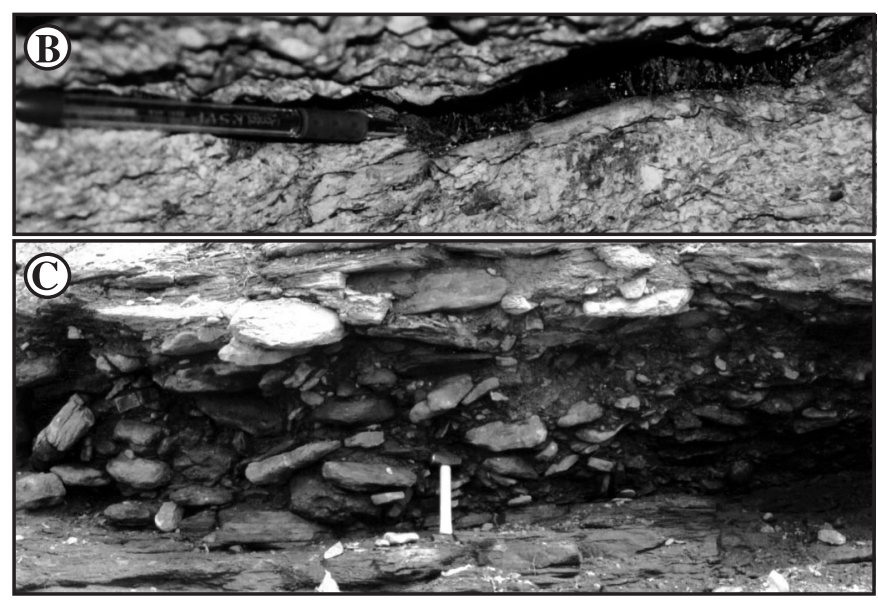

conglomerate (Devonian) (Fig. 2, locality 4) is the product of intense weathering of the exposed basement surface, which would have occurred prior to deposition of the Cannes-de-Roches Formation. This interpretation is supported by the fact that the basal calcrete, below both the Bonaventure and Cannes-de-Roches formations, show a sharp contact with the overlying clastic sedimentary rocks, but a gradational one with the underlying basement. However, gravel-size volcanic clasts are found in the groundwater calcrete of the Cannes-de-Roches Cove sequence, on the south shore of Mal Bay (Fig. 2, locality 5), although similar clasts are not found in the underlying Matapedia Group limestone basement. The calcrete, therefore, developed within a coarse sediment overlying the basement and bearing volcanic rocks.

Furthermore, the interpretation of Rust (1982) does not correspond to any known case of calcrete formation. The thorough synthesis on calcrete genesis by Wright and Tucker (1991) does not mention any process in which an exposed surface is directly affected by the deep mineral replacement and displacement that is implied in the interpretation of Rust (1982). Laminar calcrete, which is the only one developing directly on bedrock, is much thinner, does not penetrate the bedrock surface, and has a clearly different structure that can sometimes be confused with stromatolites (Wright 1989). The only calcrete known to develop to a thickness exceeding $3 \mathrm{~m}$ is groundwater calcrete, occurring under the water table in thick unconsolidated sediments.

The discovery of the La Coulée Formation (Jutras et al. 1999) offers new insights into the genesis of the thick calcretes that are commonly found between basement rocks and both the Bonaventure and Cannes-de-Roches formations. The coarse clastic sedimentary rocks of the La Coulée Formation were deeply affected by groundwater calcretization and were later uplifted and almost entirely eroded prior to sedimentation of the Bonaventure Formation, which has buried the few erosional remnants of the former unit. The basal calcretes, one of which clearly shows a stepped topography below the Bonaventure Formation at the northern tip of Bonaventure Island (Fig. 2, locality 7), are interpreted as being more widespread remnants of the $\mathrm{La}$ Coulée Formation, due to their higher resistance to erosion 
Fig. 13. Depth above base of section, age, spore zone, and vertical distribution of palynomorphs in the Pointe Sawyer Formation at the Cannes de Roches Cove and Pointe Sawyer localities (the GSC locality corresponds to the file number of each sample at the Geological Survey of Canada).

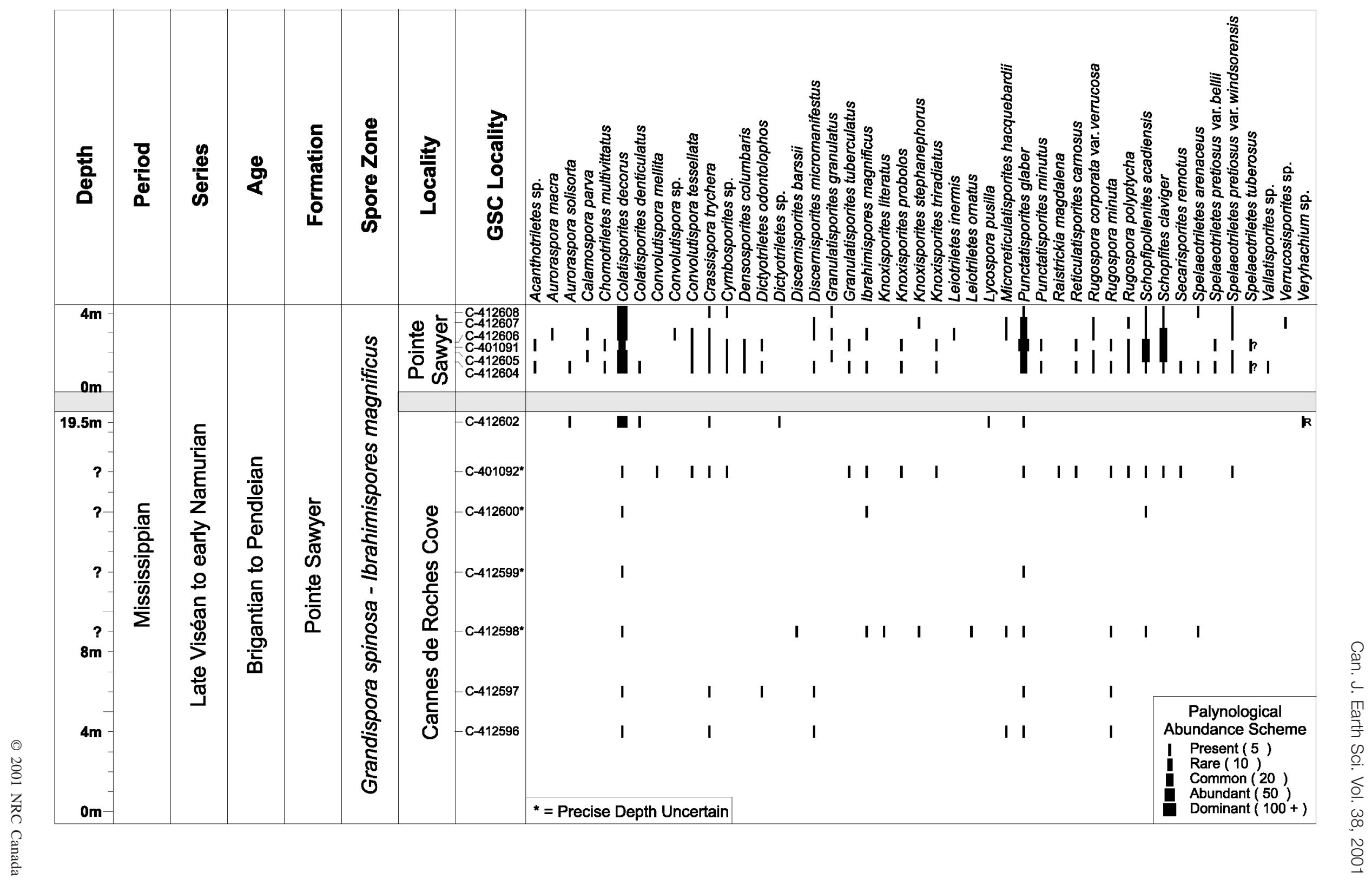


Fig. 14. Paleocurrent measurements taken from the Bonaventure Formation in the southeastern part of the Gaspé Peninsula.

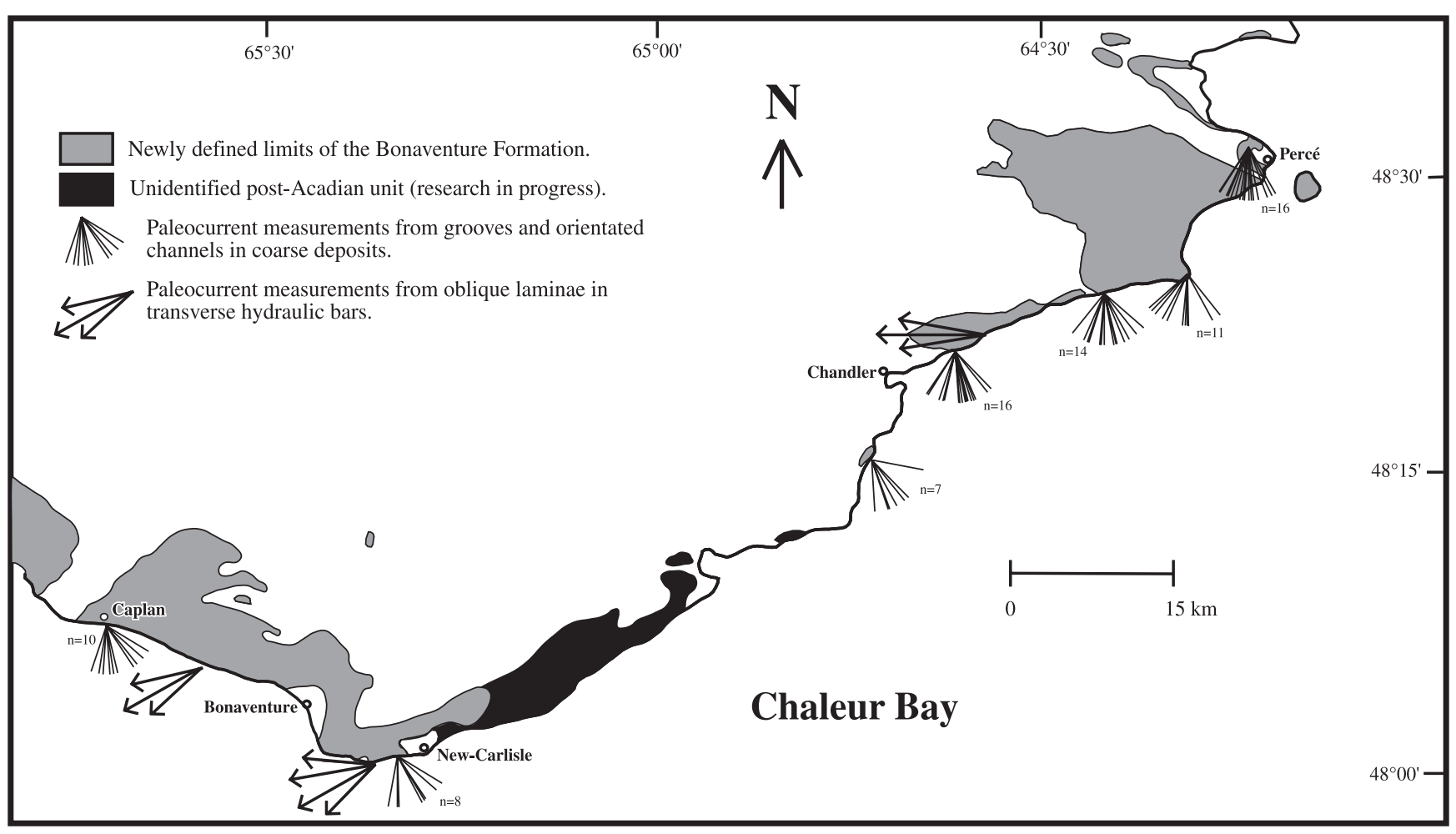

than the formerly overlying clastic material of that formation. The basal groundwater calcrete that underlies the Cannes-de-Roches Formation is also interpreted as the erosional remnant of a calcretized clastic formation. It is similar in all respects to those underlying the Bonaventure Formation and also shows the same sharp contact with similar overlying red clastic sedimentary rocks (Fig. 6). However, the presence of volcanic clasts in the Cannes-de-Roches calcrete indicates that its host sediment was not fed by exactly the same source rocks as the clastic sequence of the La Coulée Formation at Mont-Sainte Anne, which is exclusively composed of calcareous clasts.

The proposition of Jutras et al. (1999) to map the groundwater calcrete hardpans underlying the Bonaventure Formation as erosional remnants of the La Coulée Formation, even though the nature of the host sediment cannot always be determined, is extended to those found underneath the Cannesde-Roches Formation. Although groundwater calcretes should be regarded as postsedimentary diagenetic overprints, rather than stratigraphic units, they are rare enough in the geological record to be used as reliable stratigraphic markers. The thick and massive groundwater calcrete hardpans of the La Coulée Formation are the first reported occurrences of such calcrete facies in pre-Quaternary deposits (Jutras et al. 1999). The environmental needs for massive groundwater calcrete formation are so specific that it is very unlikely that the few occurrences within the Carboniferous rocks of Gaspé would represent more than one event. To date, no exposure has challenged the hypothesis that the various groundwater calcretes of Gaspé occupy the same stratigraphic position.

The La Coulée Formation is interpreted, from the absence of plant debris and from its extensive groundwater calcretization, as having evolved under a relatively arid climate (Jutras et al. 1999). Based on modern settings (e.g., Arakel and McConchie 1982; Arakel et al. 1989; Jacobson et al. 1988; Mann and Horwitz 1979), proximal drainage connections to salt lakes, playas, or an abandoned sea-arm is inferred (Jutras et al. 1999). Such massive groundwater calcrete formation occurs in the zone where fresh groundwater mixes with the saline groundwater of an evaporitic basin (Arakel et al. 1989; Jacobson et al. 1988).

\section{The Bonaventure Formation (red clastics)}

In the Percé - Mont Sainte-Anne sequence, the first $25 \mathrm{~m}$ of the Bonaventure Formation are interpreted, from the high lateral variability and the chaotic nature of the conglomerate, to be distal alluvial fan material deposited during sudden and ephemeral events, such as debris flows and flash floods. We agree with the conclusions of Rust (1984) and Rust et al. (1989) that such deposits must be the product of faultcontrolled sedimentation. The overlying $25 \mathrm{~m}$, containing finer fractions, are interpreted to represent the rapid passage from gravelly to sandy braidplain deposits, probably resulting from a slowing down of fault activity. The persistency of coarse conglomerate for over $300 \mathrm{~m}$ in the rest of the sequence probably resulted from massive debris flows and flash floods in a rejuvenated alluvial fan environment generated by renewed fault activity.

The first half of the Bonaventure Formation in the NewCarlisle sequence (i.e., the lowermost $\sim 25 \mathrm{~m}$ ) is interpreted as fluctuations from gravelly braidplain deposits to sandy braidplain and proximal alluvial plain deposits. As was mentioned earlier, the thick planar cross-strata that are abundant in the upper half of the sequence are interpreted, from their lateral persistency over hundreds of metres, as prograding 
Fig. 15. Alternations of breccia and conglomerate beds in the Bonaventure Formation at Percé.

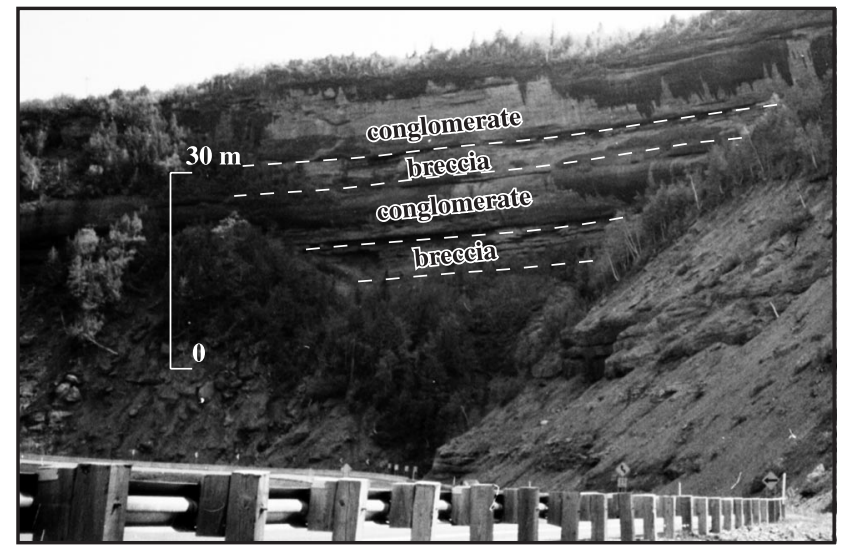

transverse hydraulic bar deposits. As the paleocurrent directions are perpendicular to those of the underlying alluvial fan and gravelly braidplain deposits (Fig. 14), the deposits are interpreted as belonging to trunk river systems. Such rivers are interpreted as having flowed parallel to the fault scarp from which clastic material issued, whereas flows from alluvial fans radiated perpendicular to the fault scarp. As for the oblique hardpans that are found near the top of the sequence (Fig. 11), from the way they follow internal structures, it is clear that they are not pedogenic but were rather precipitated from groundwater circulation.

The Lower Member of the Cannes-de-Roches Formation is also interpreted as belonging to a fault-related alluvial fan complex (Rust 1981). The environment of the Middle Member is interpreted as the distal equivalent of the Lower Member, a muddy braidplain intermittently receiving distal flood deposits (Rust 1981; Rust et al. 1989).

These two members have the same overall appearance, structure, and composition as the Bonaventure Formation. The same succession of fault-related alluvial fan, gravelly braidplain, and alluvial plain sediments, which would have evolved under an arid climate, is found in both sequences (Rust 1981; Zaitlin and Rust 1983). They notably have the same characteristic deep orange-red colour. Also, both show a predominance of limestone clasts and other locally derived rock types in their conglomeratic beds, along with abundant quartz pebbles and occasional red jasper (refer to samples 13-20 of Table 1 for sandstone composition). They also show the same characteristic green mineralization haloes around manganese-rich clasts, and numerous nodular pedogenic calcretes (Figs. 4A, 4B, 4C).

The red clastic sedimentary rocks of the Cannes-deRoches Formation are not only very similar in terms of facies to the Bonaventure Formation, but are also in stratigraphic contact with the same units, namely the underlying groundwater calcrete hardpans and the overlying grey clastic sedimentary rocks with plant remains. The Bonaventure Formation at Percé (Fig. 4B) is much thicker than the red clastic sedimentary rocks of the Cannes-de-Roches Cove (Fig. 4A), but it is much thicker than those of the New Carlisle area as well (Fig. 4C), which are also within the former limits of that unit.

As for the interdigitation between the Bonaventure and Cannes-de-Roches formations that was reported by
Kirkwood (1989) for the Percé region, we believe that confusion may have occurred as this is one of the rare places where breccia beds, intercalated with conglomeratic beds, are found within the former limits of the Bonaventure Formation (Fig. 15), whereas the coarse fractions of the red clastic sedimentary rocks in the Cannes-de-Roches Cove are typically more brecciated. The breccia beds only represent more proximal deposits and cannot be used to differentiate two formations.

We suggest abandoning the terms "Lower and Middle members" of the Cannes-de-Roches Formation as stratigraphic names since there is no apparent reason to differentiate these units from the Bonaventure Formation, which is more widely distributed and was identified first by Logan (1846).

Rust (1981) demonstrated that the clastic redbeds of the Cannes-de-Roches Cove sequence have southwest-trending paleocurrents on the north shore of Mal Bay, opposing northeast-trending paleocurrents on the south shore. From this and from facies distribution, he defined approximate limits to the paleovalley in which they were deposited (Fig. 16).

Zaitlin and Rust (1983) defined, from numerous paleocurrent data, the approximate limits of the much larger paleovalley in which the classic Bonaventure sequence was deposited and which corresponds to the limits of the Chaleur Bay depression. van de Poll (1995) refers to this paleovalley as the Ristigouche Basin (Fig. 16). The measurements taken by Zaitlin and Rust (1983) were concentrated in the western part of the basin and some conclusions regarding the drainage system of the entire basin were drawn from there.

Complementary paleocurrent data from the eastern part of the Ristigouche Basin have been collected in the Bonaventure Formation for this study. Figure 14 shows that paleocurrents in coarse alluvial fan and gravelly braidplain deposits of the Bonaventure Formation are steadily to the south on the north shore of Chaleur Bay, from Chandler to Percé. From the above-mentioned paleocurrent patterns, we conclude that the much thinner Cannes-de-Roches Cove sequence, which has a distinct paleocurrent trend, was not deposited in the Ristigouche Basin, but in an adjacent one, as was first proposed by Alcock (1935), that we herein refer to as the Cannes-de-Roches Basin (Fig. 16).

Laterally and vertically persistent systems of transverse hydraulic bars, such as the ones illustrated on Figs. 10 and 11 , have been identified in three areas of the Ristigouche Basin and indicate that trunk rivers, perpendicular to alluvial fans, were flowing steadily to the west or to the southwest. This contradicts the model of Zaitlin and Rust (1983), which suggested that ultimate drainage of the Ristigouche Basin was to the east (Fig. 16).

Deposits from large west-flowing trunk river systems are only found quite high in the stratigraphy of the Bonaventure Formation, and it is possible that they represent a general flow reversal during the evolution of the basin. However, the pre-Carboniferous basement rocks extending to the west of Chaleur Bay are topographically higher than the above-mentioned Carboniferous trunk river deposits and, as there are no faults in between that could have been the locus of posterior block displacement between the two sectors, this probable paleorelief makes it unlikely for Carboniferous drainage 
Fig. 16. Paleogeographic reconstruction of the Ristigouche, Cannes-de-Roches, and Maritimes basins during sedimentation of the Bonaventure Formation.

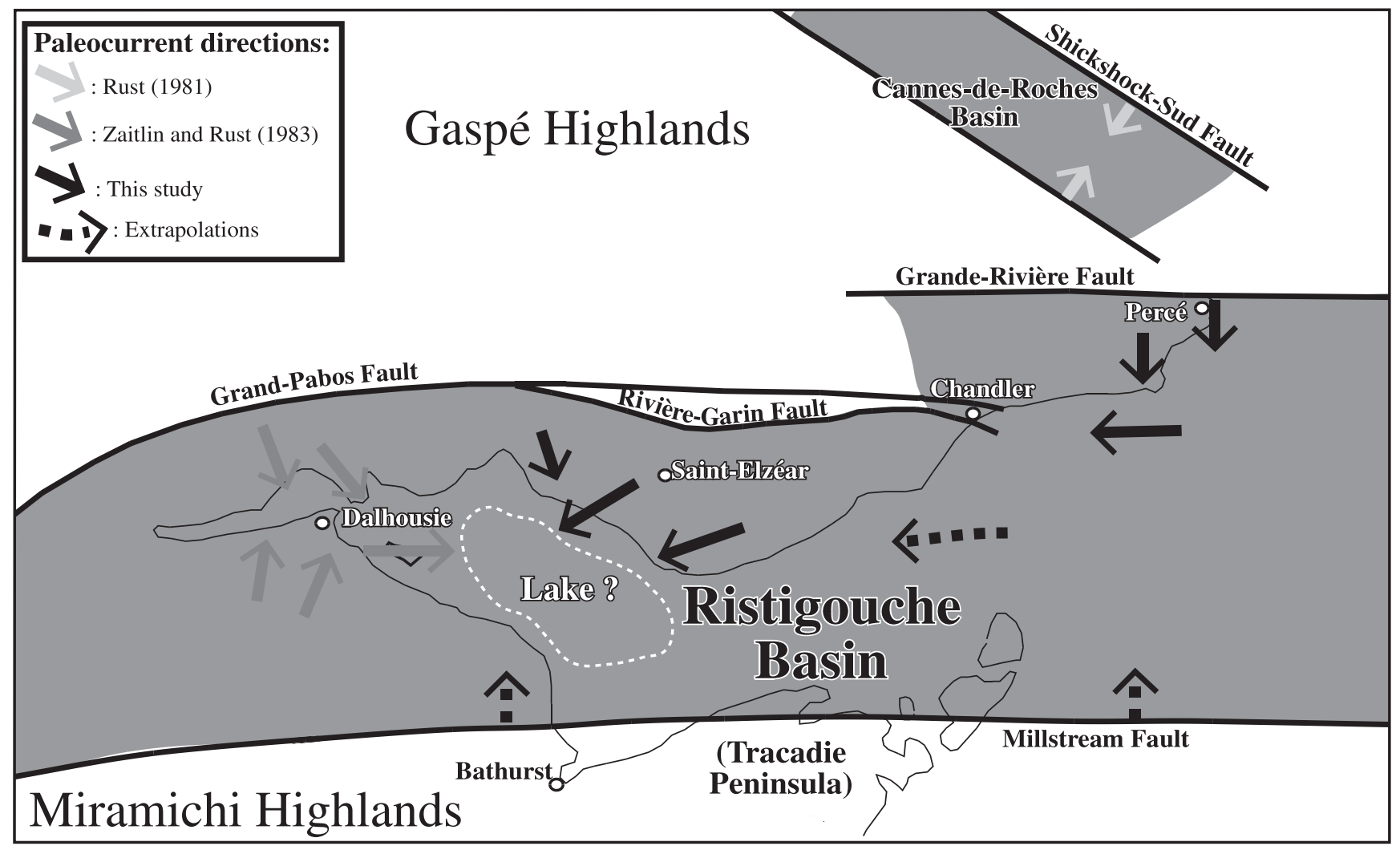

to have maintained its westward trend much further. Carboniferous paleorelief is even steeper to the north (Gaspé Highlands) and to the south (Miramichi Highlands) (Jutras and Schroeder 1999; Peulvast et al. 1996), and it thus seems probable that general drainage would have been trapped within the western part of the Ristigouche Basin. If this was the case, the rivers that built the thick transverse bars were then probably large enough to feed a big lake at approximately the same locality than present-day western Chaleur Bay (Fig. 16).

As was mentioned earlier, the Bonaventure Formation, including what was formerly called the Lower and Middle members of the Cannes-de-Roches Formation, has been attributed to fault-related sedimentation from the high lateral variability of its continental deposits (Rust 1981, 1984; Rust et al. 1989; Zaitlin and Rust 1983). Rust et al. (1989) proposed that the Bonaventure Formation was the product of dip-slip related sedimentation from the presence of inversely graded conglomerate channels which, they argued, suggest dip-slip rejuvenation. However, such rejuvenation could also be pictured in the context of oblique strike-slips.

From facies distribution and paleocurrent directions, it can be estimated that the main faults responsible for sedimentation of the Bonaventure Formation are, most realistically, (1) the Grand-Pabos and possibly the Rivière-Garin faults in the northwestern part of the Ristigouche Basin, (2) the Grande-Rivière Fault in the northeastern part, (3) the Millstream Fault in the southern part, and (4) the Shickshock-Sud fault in the northeastern part of the Cannesde-Roches Basin (Fig. 16). These correlations are proposed from the geographic relationship between the deposits and the main structures of the region.

\section{The Pointe Sawyer Formation (grey clastics with plant remains)}

From their equivalent facies and similar spore assemblage, it is clear that the grey clastics at Pointe Sawyer are the lateral equivalents of the Upper Member of the Cannes-deRoches Formation. This unit was thought to be synchronous with the red clastics of the Bonaventure Formation, but characteristic of the Cannes-de-Roches Formation, which would have evolved in a slightly different environment where vegetation was able to proliferate (Alcock 1935; Rust 1981).

Noticing a $90^{\circ}$ difference in paleocurrent directions between the red and the grey clastics of the former Cannes-deRoches Formation, Rust (1981) proposed a model where the grey clastics were lateral equivalents of the red clastics, but associated with a trunk river system flowing perpendicular to the alluvial fans (Fig. 17). According to this model, oxidization would not have occurred at the level of the trunk river system, the water table being closer to surface there than at the level of the nearby alluvial fans. This model is also supported by the fact that the grey clastics of the Cannes-deRoches Formation have more rounded clasts and were subject to longer transportation than the underlying red clastics (Rust 1981).

There is, however, nothing in the stratigraphic arrangement of the Cannes-de-Roches Cove sequence that suggests a gradually prograding system of grey clastics over red clastics; the change from red to grey strata in Cannes-de- 
Fig. 17. Depositional model for the Cannes-de-Roches Formation by Rust (1981). R, red; B, buff; G, grey-green.

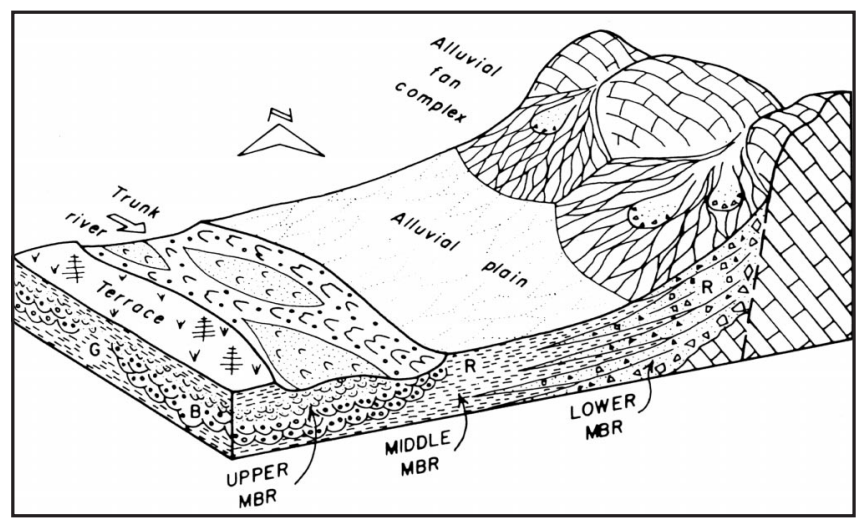

Roches Cove is quite sharp and shows coarse grey conglomerates overlying red mudstones. However, as was noted above, the collapse of subvertical strata obscures the contact between the two units in Cannes-de-Roches Cove, which leaves some uncertainties on its original sedimentologic nature.

A channel contact between the red and grey clastics with plant remains is well preserved at Pointe Sawyer, revealing a small erosional disconformity between the two units (Fig. 12). There, the drastic change in facies is clearly related to an overall environmental change, because trunk river systems, red throughout, are identified in the underlying Bonaventure Formation from the presence of numerous and laterally persistent transverse hydraulic bar systems (Figs. 10 and 11).

Following procedures from the International Subcommission on Stratigraphic Classification (Hedberg et al. 1976), abandonment of the name Cannes-de-Roches is suggested for the remaining Upper Member to avoid confusion regarding the limits of that formation. Since the discovery of the Pointe Sawyer outcrop was fundamental in assessing this grey sequence as a post-Bonaventure unit, we propose that it be referred to as the Pointe Sawyer Formation (Appendix 2).

The common occurrence of the trilete spores Schopfites claviger and Colatisporites decorus in the assemblages from the Pointe Sawyer Formation (Appendix 1) would, according to van der Zwan et al. (1985), suggest that the climate was still arid, although it may have been relatively more humid than the underlying Bonaventure Formation, which lacks spores and has more arid characteristics, such as oxidization, pedogenic calcrete, and minor groundwater calcrete lenses.

\section{The Chemin-des-Pêcheurs Formation (dark reddish- brown sandstones)}

The grey clastics are overlain conformably by dark reddish-brown sandstone in the Cannes-de-Roches Cove (Figs. 4A and 9). The transition is gradational but marked. The change in colour may be due to a return to more severely arid conditions, which is also suggested by the fact that plant fragments are no longer present. The change may have been quite sudden, as suggested by the abundance of large plant fragments, some of which may represent tree trunks, at the top of the Pointe Sawyer Formation (Fig. 8).
Perhaps the most significant change is the sudden scarcity of calcite as cement and limestone debris in the Chemin-desPêcheurs Formation (Fig. 5C), which was a major component in the underlying clastic sequences from the coarsest breccia to the finest muddy strata. As limestone is so well represented in the pre-Carboniferous basement geology of the Gaspé Peninsula and northern New Brunswick, this must reflect a much more distant sediment source for the dark reddish-brown sandstone than for the underlying clastic sequences. This passage from proximal to distal sedimentation sources is observed diachronously in all of Atlantic Canada at approximately the mid-Carboniferous. The Maritimes Basin was dominated by fault-related sedimentation in the Late Devonian and Mississippian, while it mainly acted as a passive basin in the Pennsylvanian and Early Permian, collecting sediments from drainage systems whose sources were within the Alleghanian Orogen, which was being uplifted to the south (Gibling et al. 1992; Thomas and Schenk 1988).

Being in conformable and gradational contact with the underlying Pointe Sawyer Formation, of the late Viséan (Brigantian) to early Namurian (Pendleian), deposition of the dark reddish-brown unit probably began during the Namurian, which may correspond to the approximate time when the northwest periphery of the Maritimes Basin would have started to receive sediments from the Alleghanian Orogen. This corresponds relatively well with the model of Gibling et al. (1992), in which drainage from the Alleghanian Orogen is suggested for the whole Pennsylvanian subperiod, starting in the middle of the Namurian. According to Slingerland and Furlong (1989), however, the Alleghanian chain first developed at the level of the southern United States, in the early Pennsylvanian, and peak deformation at the New England level only occurred in the Early Permian. Consequently, the probable Namurian age of the dark reddish-brown sandstone makes an Alleghanian provenance less likely.

Alternatively, cases of river antecedence with a northsouth axis are reported in the north-central highlands of the Gaspé Peninsula (Mattinson 1964). Jutras and Schroeder (1999) proposed, from geologic and geomorphic constraints, that these rivers must have maintained their trajectory during a late Paleozoic to early Mesozoic epeirogenic uplift in that region. As the south of the Peninsula acted mainly as a graben or half-graben structure, the source of these rivers, starting sometime in the late Paleozoic, must have been to the north, from the nearby Canadian Shield.

No paleocurrent data are available from the rare outcrops of these perfectly laminar sandstones to test the hypothesis that the source was either from the Alleghanian chain, to the south, or from the Precambrian craton, to the north. However, the absence of feldspar grains, the small amount of metamorphic quartz and gneissic fragments (1-2\%), and the presence of sedimentary rock fragments $(\sim 10 \%)$ do not support the hypothesis of a Precambrian source, but rather suggest an Appalachian source.

These dark reddish-brown sandstones, which are the topmost unit of what remains of the Cannes-de-Roches Cove sequence, have not been mentioned in earlier work on the former Cannes-de-Roches Formation. We propose to give this unit formation status in the light of the major environmental and petrographic changes that differentiate it from 
the underlying formations. We name it the Chemin-desPêcheurs Formation (Appendix 3), after the small dirt road that leads to the best outcrops.

\section{Correlation with the rest of the Maritimes Basin}

As was mentioned earlier, thick groundwater calcretes, such as the ones associated with the La Coulée Formation, most typically develop at the periphery of evaporitic basins. In the upper Paleozoic stratigraphy of the Maritimes, such an environment is commonly represented in the strata of the Windsor Group. Moreover, the calcrete at Saint-Elzéar (Fig. 2, locality 8) overlies a surface that is interpreted as having been carved by coastal marine erosion (Jutras and Schroeder 1999). Carboniferous marine erosion extending so far to the northwest can be best correlated with the base of the middle Viséan Lower Windsor, which consists of limestone of the Macumber Formation originating from a most extensive transgressive episode, quickly followed by regression and thick deposition of evaporitic material (Geldsetzer 1977; Lynch and Giles 1995). The groundwater calcretes of the La Coulée Formation may have developed during the regressive lowstand that followed maximum transgression and left numerous evaporitic basins. A direct relationship between groundwater calcretization and regressive lowstands has been proposed in other studies (Sanborn 1991; Tandon and Gibling 1997).

The La Coulée Formation is known to be post-Middle Devonian as it lies unconformably on Acadian structures. Biostratigraphic data is unavailable to further constrain the age of this unit. However, based on geomorphic, lithostratigraphic, and paleoenvironmental criteria, deposition of the La Coulée Formation most likely followed the Macumber Formation event (middle Viséan), and thus the former may be correlated with the evaporite deposits of the upper part of the Lower Windsor Group.

The spore assemblage of the Pointe Sawyer Formation, which belongs to the Grandispora spinosa - Ibrahimispores magnificus (SM) Zone (late Viséan to early Namurian), is younger than the Schopfipollenites acadiensis Knoxisporites triradiatus (AT) Zone (late Viséan), which is characteristic of the Upper Windsor Group, whereas the SM Zone is characteristic of the Mabou (or Canso) Group (Utting 1987). The underlying redbeds of the Bonaventure Formation, which lack biostratigraphic data, are possibly also equivalent to the Mabou Group; a hypothesis supported by the fact that this unit is separated from the underlying La Coulée Formation by a significant unconformity, which would best correlate with the one that separates the Windsor and Mabou (or Canso) groups in various sectors of the Maritimes (Howie and Barss 1975).

It should be pointed out that the age ranges assigned to the AT and SM palynological zones do not correspond to the age attributed to the marine fauna that is found at the same stratigraphic level. Mamet (1970), based on foraminifers, assigned the uppermost carbonate of the Upper Windsor Group to the Namurian. However, this unit contains the AT spore assemblage, which lacks any spore taxa diagnostic of the Namurian. If the age determinations of the marine fauna are correct, the SM Zone is Namurian. The biostratigraphic uncertainty at the Viséan-Namurian boundary is currently being investigated.

As was mentioned earlier, the Chemin-des-Pêcheurs Formation is probably Namurian and therefore also correlates with the Mabou Group. It must have blanketed the whole Chaleur Bay region prior to post-Carboniferous erosion, as must the Pennsylvanian to Permian beds of the Pictou Group, which occupy the south shore of the Bay and most of the Gulf of St. Lawrence (Legun and Rust 1982; van de Poll 1973). According to Ryan and Zentilli (1993), 1-4 km of the original late Paleozoic cover of the Maritimes has been eroded since Permian time, most of it prior to the Jurassic (also see Howie and Barss 1975 and van de Poll et al. 1995, for a synthesis of the upper Paleozoic stratigraphy of the Maritimes).

\section{Conclusions}

The thin Cannes-de-Roches Cove sequence, which occupies the south shore of Mal Bay and which was previously included within the Cannes-de-Roches Formation by Alcock (1935), is a condensed version of the Carboniferous stratigraphy in the larger Ristigouche Basin, occupying most of the Chaleur Bay depression. It was synchronously deposited in a different basin that we propose to refer to as the Cannes-deRoches Basin.

Four Carboniferous formations are recognized in the Cannes-de-Roches Basin, three of which are also found in the Ristigouche Basin:

(1) Calcretized remnants of the La Coulee Formation (Jutras et al. 1999) are sporadically found at the base of the succession in both basins. From geomorphic, lithostratigraphic, and paleoenvironmental constraints, this nondated unit is tentatively correlated with the Lower Windsor Group (middle Viséan).

(2) The former Lower and Middle members of the Cannesde-Roches Formation are correlated with the Bonaventure Formation, which unconformably overlies the La Coulée Formation. This unconformity is tentatively correlated with the one that separates the Windsor and Mabou groups of Nova Scotia and New Brunswick. In this view, the Bonaventure Formation would represent the basal Mabou (late Viséan or early Namurian). Faults responsible for sedimentation of the Bonaventure Formation in the southern Gaspé Peninsula were to the north, and drainage of trunk river systems, perpendicular to the alluvial fans, was mainly to the west or southwest, except for the western extremity of the basin where eastward paleodrainage has been previously interpreted (Zaitlin and Rust 1983). Eastward and westward drainage probably merged into a lake.

(3) The Upper Member of the former Cannes-de-Roches Formation, which records the passage from arid to slightly less arid conditions in the late Viséan or early Namurian, is now referred to as the Pointe Sawyer Formation, which can also be observed outside of the Cannes-de-Roches Basin, southeast of the town of Bonaventure. The spore assemblage of this formation correlates with Mabou units in the rest of the Maritimes Basin. 
(4) A fourth formation, which only crops out at the top of the Cannes-de-Roches Cove sequence and which corresponds to a return to more oxic conditions, has also been recognized and named Chemin-des-Pêcheurs Formation. This noncalcareous formation (Namurian?) is also tentatively correlated with the Mabou Group and is notably the first record of sedimentation from distant sources in the post-Acadian sequence of the Gaspé Peninsula, which, till then, was characterized by proximal, fault-related sedimentation.

\section{Acknowledgments}

We wish to thank M. Gibling and M. Melchin for very constructive reviews. We also thank Michel Préda (Research Associate) for X-ray diffraction analysis and are grateful to Brenda Davies of the Geological Survey of Canada (Calgary), who processed the palynology samples. This study is financed partly by the Natural Science and Engineering Research Council of Canada.

\section{References}

Alcock, F.J. 1935. Geology of the Chaleur Bay region. Geological Survey of Canada, Memoir 183.

Arakel, A.V., and McConchie, D. 1982. Classification and genesis of calcrete and gypsite lithofacies in paleodrainage systems of inland Australia and their relationship to carnotite mineralization. Journal of Sedimentary Petrology, 52: 1149-1170.

Arakel, A.V., Jacobson, G., Salehi, M., and Hill, C.M. 1989. Silicification of calcrete in paleodrainage basins of the Australian arid zone. Australian Journal of Earth Sciences, 36: 73-89.

Bell, W.A. 1944. Carboniferous rocks and fossil floras of Northern Nova Scotia; Geological Survey of Canada, Memoir 238.

Bourque, P.A., et Lachambre, G. 1980. Stratigraphie du Silurien et du Dévonien basal du sud de la Gaspésie. Ministère de l'Énergie et des Ressources, Québec, ES-30.

Brisebois, D. Lachambre, G., et Piché, G. 1992. Carte géologique: Péninsule de la Gaspésie. Ministère de l'Énergie et des Ressources, Québec, DV 91-21.

Clayton, G., Coquel, R., Doubinger, J., Guein, K.J., Loboziac, S., Owens, B., and Streel, M. 1977. Carboniferous spores of western Europe. Illustration and zonation. Report of Commission Internationale de microflore du Paléozoïque, Working Group on Carboniferous Stratigraphical Palynology, 29.

Dunham, R.J. 1962. Classification of carbonate rocks according to depositional texture. American Association of Petroleum Geologists, Memoir 1, pp. 108-121.

Geldsetzer, H.H. 1977. The Windsor Group of Cape Breton Island, Nova Scotia. Geological Survey of Canada, Paper 77-1A, pp. 425-428.

Gibling, M.R., Calder, J.H., Ryan, R., van de Poll, H.W., and Yeo, G.M. 1992. Late Carboniferous and Early Permian drainage patterns in Atlantic Canada. Canadian Journal of Earth Sciences, 29: $338-352$.

Globensky, Y. 1993. Lexique Stratigraphique Canadien; Volume 5B; Région des Appalaches, des Basses-Terres du St.-Laurent et des Îles de la Madeleine. Gouvernement du Québec, DV 91-23.

Hacquebard, P.A. 1972. The Carboniferous of Eastern Canada. Seventh International Carboniferous Congress, Krefeld, 1971, Compte rendu 1, pp. 69-90.

Harland, W.B., Armstrong, R.L., Cox, A.V., Craig, L.E., Smith, A.G. And Smith, D.G. 1990. A geological time scale 1989. Cambridge University Press, Cambridge, U.K.
Hedberg, H.D., Neville, G., Pomerol, C., Salvador, A., and Stöcklin, J. 1976. International Stratigraphic Guide; a guide to stratigraphic classification, terminology, and procedure. By International Subcommission on Stratigraphic Classification (ISSC). Edited by H.D Hedberg. John Wiley and Sons, New York.

Howie, R.D., and Barss, M.S. 1975. Upper Paleozoic rocks of the Atlantic provinces, Gulf of St. Lawrence and adjacent continental shelf. Geological Survey of Canada, Paper 74-30, Vol. 2, pp. 35-50.

Jacobson, G., Arakel, A.V., and Chen Yijian 1988. The central Australian groundwater discharge zone: evolution of associated calcrete and gypcrete deposits. Australian Journal of Earth Sciences, 35: 549-565.

Jutras, P., and Schroeder, J. 1999. Geomorphology of an exhumed Carboniferous paleosurface in the southern Gaspé Peninsula; paleoenvironmental and tectonic implications. Géographie Physique et Quaternaire, 53: 249-263.

Jutras, P., Prichonnet, G., and von Bitter, P. 1999. The La Coulée Formation, a new post-Acadian continental clastic unit bearing groundwater calcretes, Gaspé Peninsula, Québec. Atlantic Geology, 52: 139-156

Kirkwood, D. 1989. Géologie structurale de la région de Percé Ministère de l'Énergie et des Ressources, Québec, ET 87-17.

Legun, A.S., and Rust, B.R. 1982. The Upper Carboniferous Clifton Formation of northern New Brunswick: coal-bearing deposits of a semi-arid alluvial plain. Canadian Journal of Earth Sciences, 19: 1775-1785.

Logan, W.E. 1846. Sections on Chaleur Bay and coast of Gaspe. Geological Survey of Canada, Progress in Report, pp. 78-110.

Lynch, G., and Giles, P.S. 1995. The Ainslie detachment: a regional flat-lying extensional fault in the Carboniferous evaporitic Maritimes Basin of Nova Scotia, Canada. Canadian Journal of Earth Sciences, 33: 169-181.

Mamet, B.L. 1970. Carbonate microfacies of the Windsor Group (Carboniferous), Nova Scotia and New Brunswick. Geological Survey of Canada, Paper 70-21.

Mann, A.W., and Horwitz, R.C. 1979. Groundwater calcrete deposits in Australia: some observations from Western Australia. Journal of the Geological Society of Australia, 26: 293-303.

Mattinson, C.R. 1964. Région du Mont Logan. Ministère de l'Énergie et des Ressources, Québec, RG 118.

McGerrigle, H.W. 1950. La géologie de l'est de Gaspé. Ministère des Mines, Québec, RG 35.

Pettijohn, F.J. 1975. Sedimentary rocks. Harper and Row, New York.

Peulvast J.-P., Bouchard, M., Jolicoeur, S., Pierre, G., and Schroeder, J. 1996. Paleotopographies and post-orogenic morphotectonic evolution around the Baie-des-Chaleurs (Eastern Canada). Geomorphology, 16: 5-32.

Rust, B.R. 1976. Stratigraphic relationships of the Malbaie Formation (Devonian), Gaspé, Québec. Canadian Journal of Earth Sciences, 13: 1556-1559.

Rust, B.R. 1981. Alluvial deposits and tectonic style; Devonian and Carboniferous successions in Eastern Gaspé. In Sedimentation and tectonics in alluvial basins. Edited by A.D. Miall. Geological Association of Canada, Special Paper 23, pp. 49-76.

Rust, B.R. 1982. Devonian and Carboniferous continental sedimentation of southern Gaspé peninsula. In Paleozoic continental margin sedimentation in the Quebec Appalachians. Edited by R. Hesse, G.V. Middleton, and B.R. Rust. 11th International Congress of Sedimentology, Excursion 7b Guidebook, McGill University, Montréal, P.Q. pp. 69-96.

Rust, B.R. 1984. Proximal braidplain deposits in the Middle Devonian Malbaie Formation of Eastern Gaspé, Quebec, Canada. Sedimentology, 31: 675-695. 
Rust, B.R., Lawrence, D.A., and Zaitlin, B.A. 1989. The sedimentation and tectonic significance of Devonian and Carboniferous terrestrial successions in Gaspé, Québec. Atlantic Geology, 25: 1-13.

Ryan, R.J., and Zentilli, M. 1993. Allocyclic and thermochronological constraints on the evolution of the Maritimes Basin of eastern Canada. Atlantic Geology, 29: 187-197.

Ryan, R.J., Boehner, R.C., and Calder, J.H. 1991 Lithostratigraphic revisions of the Upper Carboniferous to Lower Permian strata in the Cumberland Basin, Nova Scotia and their regional implications for the Maritimes Basin in Atlantic Canada. Bulletin of Canadian Petroleum Geology, 39: 289-314.

Sanborn, R.K. 1991. Petrography and geochemistry of a calcrete profile from the northwestern coast of the Yucatan Peninsula, Chubarna, Yucatan, Mexico. Unpublished M.Sc. thesis, Northwest Illinois University, De Kalb, Ill.

Slingerland, R., and Furlong, K.P. 1989. Geodynamic and geomorphic evolution of the Permo-Triassic Appalachian Mountains. Geomorphology, 2: 23-37.

Tandon, S.K., and Gibling, M.R. 1997. Calcretes at sequence boundaries in Upper Carboniferous cyclothems of the Sydney Basin, Atlantic Canada. Sedimentary Geology, 112: 43-57.

Thomas, W.A., and Schenk, P.E. 1988. Late Paleozoic sedimentation along the Appalachian orogen. In The CaledonianAppalachian Orogen. Edited by A.L. Harris and D.J. Fettes. Geological Society, Special Publication 38, pp. 515-530.

Utting, J. 1987. Palynology of the Lower Carboniferous Windsor Group and Windsor-Canso boundary beds of Nova Scotia, and their equivalents in Québec, New Brunswick and Newfoundland. Geological Survey of Canada, Bulletin 374.

Utting, J., Goodarzi, F., Dougherty, B.J., and Henderson, C.M. 1989a. Thermal maturity of Carboniferous and Permian rocks of the Sverdrup Basin, Canadian Arctic Archipelago, Geological Survey of Canada, Paper 89-19.

Utting, J., Keppie, J.D., and Giles, P.S. 1989b. Palynology and stratigraphy of the Lower Carboniferous Horton Group, Nova Sco- tia. In Contributions to Canadian Paleontology, Geological Survey of Canada, Bulletin 396, pp. 117-143.

van de Poll, H.W. 1973. Stratigraphy, sediment dispersal and facies analysis of the Pennsylvanian Pictou Group in New Brunswick. Maritime Sediments, 9: 72-77.

van de Poll, H.W. 1995. Upper Paleozoic rocks; New Brunswick, Prince Edward Island and Îles-de-la-Madeleine. In Geology of the Appalachian / Caledonian Orogen in Canada and Greenland. Edited by H. Williams. Geological Survey of Canada, Geology of Canada, No. 6 (also Geological Society of America, Geology of North America, Vol. F-1), pp. 455-492.

van de Poll, H.W., Gibling, M.R., and Hyde, R.S. 1995. Upper Paleozoic rocks. Introduction. In Geology of the Appalachian / Caledonian Orogen in Canada and Greenland. Edited by H. Williams. Geological Survey of Canada, Geology of Canada, No. 6, (also Geological Society of America, Geology of North America, Vol. F-1), pp. 447-454.

van der Zwan, C.J., Boulter, M.C., and Hubbard, R.N.L.B. 1985. Climatic change during the Lower Carboniferous in Euramerica, based on multivariate stastical analysis of palynological data. Palaeogeography, Palaeoclimatatology, Palaeoecology, 52: 1-20.

Veillette, J.J., et Cloutier, M. 1993. Géologie des formations en surface, Gaspésie, Québec. Geological Survey of Canada, Map 1804A, scale $1: 250000$.

Wright, V.P. 1989. Terrestrial stromatolites and laminar calcretes: a review. Sedimentary Geology, 65: 1-13.

Wright, V.P., and Tucker, M.E. 1991. Calcretes: an introduction. In Calcretes. Edited by V.P. Wright and M.E. Tucker. International Association of Sedimentologists, Reprint Series Volume 2, Blackwell Scientific Publications, Oxford, U.K., pp. 1-22.

Zaitlin, B.A., and Rust, B.R. 1983. A spectrum of alluvial deposits in the Lower Carboniferous Bonaventure Formation of the Western Chaleur Bay area, Gaspé and New Brunswick, Canada. Canadian Journal of Earth Sciences, 20: 1098-1110. 


\section{Appendix 1.}

Table A1.

\section{LOCALITIES}

COMPOSITE LIST OF PALYNOMORPHS

Pointe Sawyer Cannes-de-Roches Cove

SPORES

Acanthotriletes sp.

Auroraspora macra Sullivan, 1968

Auroraspora solisorta Hoffmeister, Staplin and Malloy, 1955

Calamospora parva Guennel, 1958

Chomotriletes multivittatus Playford, 1978

Colatisporites decorus (Bharadwaj and Venkatachala) Williams, 1973

Colatisporites denticulatus Neville, 1973

Convolutispora mellita Hoffmeister, Staplin and Malloy, 1955

Convolutispora sp.

Convolutispora tessellata Hoffmeister, Staplin and Malloy, 1955

Crassispora trychera Neves and Ioannides, 1974

Cymbosporites sp.

Densosporites columbaris Utting, 1987

Dictyotriletes odontolophos Utting, 1987

Dictyotriletes sp.

Discernisporites barssii Utting, 1987

Discernisporites micromanifestus (Hacquebard) Sabry and Neves, 1971

Granulatisporites granulatus Ibrahim, 1933

Granulatisporites tuberculatus Hoffmeister, Staplin and Malloy, 1955

Ibrahimispores magnificus Neves, 1961

Knoxisporites literatus (Waltz) Playford, 1962

Knoxisporites probolos Utting, 1987

Knoxisporites stephanephorus Love, 1960

Knoxisporites triradiatus Hoffmeister, Staplin and Malloy, 1955

Leiotriletes inermis (Waltz) Ischenko, 1952

Leiotriletes ornatus Ischenko, 1956

Lycospora pusilla (Ibrahim) Schopf, Wilson and Bentall, 1944

Microreticulatisporites hacquebardii Utting, 1987

Punctatisporites glaber (Naumova) Playford, 1962

Punctatisporites minutus Kosanke, 1950

Raistrickia magdalena Utting, 1987

Reticulatisporites carnosus (Knox) Neves, 1964

Rugospora corporata Neves and Owens var. verrucosa Neville, 1968

Rugospora minuta Neves and loannides, 1974

Rugospora polyptycha Neves and loannides, 1974

Schopfipollenites acadiensis Utting, 1987

Schopfites claviger Sullivan, 1968

Secarisporites remotus Neves, 1961

Spelaeotriletes arenaceus Neves and Owens, 1966

Spelaeotriletes pretiosus var. bellii (Playford) Utting, 1987

Spelaeotriletes pretiosus var. windsorensis (Playford) Utting, 1987

Spelaeotriletes tuberosus Utting, 1987

Vallatisporites $\mathrm{sp}$.

Verrucosisporites sp.

ACRITARCHS

Veryhachium sp.

$\begin{array}{ll}X & \\ X & X \\ X & \\ X & X \\ X & X \\ X & X \\ X & \\ & \end{array}$

$\mathrm{X}$

$\mathrm{X}$

$\mathrm{X}$

$\begin{array}{ll}X & X \\ X & X\end{array}$

$\mathrm{X} \quad \mathrm{X}$

$\mathrm{X} \quad \mathrm{X}$

$\mathrm{X}$

$\mathrm{X} \quad \mathrm{X}$

$\mathrm{X}$

$\mathrm{X}$

$\mathrm{X}$

$\mathrm{X} \quad \mathrm{X}$

$\mathrm{X}$

$\mathrm{X} x$

$\mathrm{X} \quad \mathrm{X}$

$\begin{array}{ll}X \\ X & x \\ X & x\end{array}$

$\mathrm{X} \quad \mathrm{X}$

$X \quad X$

$\mathrm{X}$

$\begin{array}{ll} & X \\ & X \\ X & X \\ X & X\end{array}$

$\begin{array}{ll} & x \\ X & X\end{array}$

$\mathrm{x}$

$x \quad x$

$x \quad x$

$x \quad x$

$x \quad x$

$\mathrm{X} \quad \mathrm{X}$

$x \quad x$

$\mathrm{X}$

$\mathrm{X} \quad \mathrm{X}$

$\mathrm{X}$

$\mathrm{x}$

$\mathrm{X}$

$x$
$x$
$x$
$x$

\begin{tabular}{l|l}
$x$ \\
$x$ \\
$x$ \\
$x$ \\
$x$ \\
$x$ \\
$x$ \\
$x$ \\
$x$ \\
$x$ \\
$x$ \\
$x$ \\
$x$ \\
$x$ \\
$x$ \\
$x$ \\
$x$ \\
$x$ \\
$x$ \\
\hline
\end{tabular}




\section{Appendix 2: the Pointe Sawyer Formation}

Authors: Jutras, P., Prichonnet, G., and Utting, J.

Age: Carboniferous. Late Viséan (Brigantian) to early Namurian (Pendleian).

Historic: This unit was identified as the Upper Member of the Cannes-de-Roches Formation by Alcock (1935). This author considered the Cannes-de-Roches Formation to be penecontemporaneous with the Bonaventure Formation. From spore analysis, Hacquebard (1972) and Barss in Hacquebard (1972) suggested an early Namurian age (c/b zone) for this unit, whereas Barss (personnal communication in Rust 1981) proposed a Viséan age. Kirkwood (1989) and Brisebois et al. (1992) have placed the Cannes-de-Roches Formation as time-equivalent to the basal beds of the Bonaventure Formation. Globensky (1993) excluded the Cannes-de-Roches Formation from the Canadian Stratigraphic Glossary, mistakenly thinking that Rust (1976) had proposed to abandon it as a stratigraphic unit. However, Rust himself subsequently published material on the Cannes-deRoches Formation (Rust 1981, 1982; Rust et al. 1989). Following identification of the Cannes-de-Roches Formation Upper Member on top of the Bonaventure Formation, it is here proposed to abandon the Lower and Middle members, which are lateral equivalents of the Bonaventure Formation, and to raise the Upper Member to formation status. It is proposed to abandon the term Cannes-de-Roches Formation, to avoid later confusion regarding the limits of that formation, and to rename the unit Pointe Sawyer Formation.

Maximum observed thickness: $20 \mathrm{~m}$.

Distribution: The main exposures of the Pointe Sawyer Formation are on the south shore of Mal Bay, near Percé, in the Gaspé Peninsula of Quebec (UTM Zone 22A, $5377500 \mathrm{~N}, 405500 \mathrm{E}$ ), where they dip subvertically. The type section of the Cannes-de-Roches Cove (UTM Zone 22A, $5377500 \mathrm{~N}, 405500 \mathrm{E}$ ), which was the only exposure where the formation could be followed on its entire thickness, has collapsed into the sea in 1998 or 1999 . The basal beds of that formation can also be observed at Pointe Sawyer, near the town of Bonaventure (UTM Zone 22A, 5319500N, 320500E).

Lithology: Grey calcareous continental clastics with carbonized plant remains, mainly conglomerates with some sandstones and mudstones. The type section of the Cannesde-Roches Cove $(\sim 20 \mathrm{~m})$ was showing two fining-upward grey conglomeratic units separated by $1-2 \mathrm{~m}$ of buff sandstone prior to destruction of the upper half.

Stratigraphic relationships: Overlying with a small erosional disconformity the Bonaventure Formation and overlain conformably by the dark reddish-brown sandstone of the Chemin-des-Pêcheurs Formation.

\section{Appendix 3: the Chemin-des-Pêcheurs Formation}

Authors: Jutras, P., Prichonnet, G., and Utting, J.

Age: Carboniferous (Namurian).

Historic: Mapped as the Cannes-de-Roches Formation by Alcock (1935), McGerrigle (1950), Kirkwood (1989), and Brisebois et al. (1992) and as the Upper Member of the Cannes-de-Roches Formation by Rust (1981). None of these authors have mentioned or described the facies of this unit.

Minimum thickness: $10 \mathrm{~m}$.

Distribution: The only exposures of the Chemin-desPêcheurs Formation are on the south shore of Mal Bay, near Percé, in the Gaspé Peninsula of Quebec (UTM Zone 22A, $5377500 \mathrm{~N}, 405500 \mathrm{E})$. The thickest and type section $(10 \mathrm{~m})$ is at Cannes-de-Roches Point.

Lithology: Laminar, dark reddish-brown sandstone.

Statigraphic relationships: Overlying conformably the Pointe Sawyer Formation with $\sim 4 \mathrm{~m}$ of transitional pinkishredbeds, gradually taking a reddish-brown color. No overlying formation has been identified. It is the youngest sedimentary formation of the Paleozoic identified in the Gaspé Peninsula. 
